\title{
Sistemi e modelli integrati di conoscenza e visualizzazione. II 'Bosco' del Real Sito di Portici
}

\author{
Giuseppe Antuono
}

\section{Abstract}

Lo scopo del lavoro è quello di descrivere i successivi esiti di una ricerca in itinere, scaturita da un fertile confronto internazionale, finalizzata a mettere a punto un modello di gestione e valorizzazione del vasto patrimonio paesaggistico-architettonico dei numerosi Siti Reali del Mediterraneo, talvolta degradato, organizzato secondo un logico ordine compositivo letto nel rapporto imprescindibile con il progetto delle infrastrutture idriche di alimentazione dei loro Parchi, caratterizzati da corsi e specchi d'acqua collocati tra gli elementi naturali all'interno di spazi e profondità scenografici. In tal senso è stato scelto come modello campione il Sito Reale di Portici, per chiarire l'impostazione metodologica di sistema, dalla forte connotazione interdisciplinare, e nel contempo per testare l'efficacia ed efficienza degli strumenti informativi integrati, in linea con gli obiettivi del settore delle tecnologie emergenti e future (FET) - nell'ambito del Programma Quadro di Ricerca e Innovazione dell'Unione Europea 2020 - utili a ricostruzione i rapporti morfologico-compositivi e dare vita ad un ampio database relazionale per la salvaguardia e il recupero dei caratteri identitari del sistema giardini-architetture dell'acqua, oggetto nel corso degli ultimi secoli di profonde trasformazioni che ne hanno modificato la dimensione figurativa e percettiva.

\section{Parole chiave}

cultural heritage, siti reali, sistemi informativi integrati, modello virtuale.

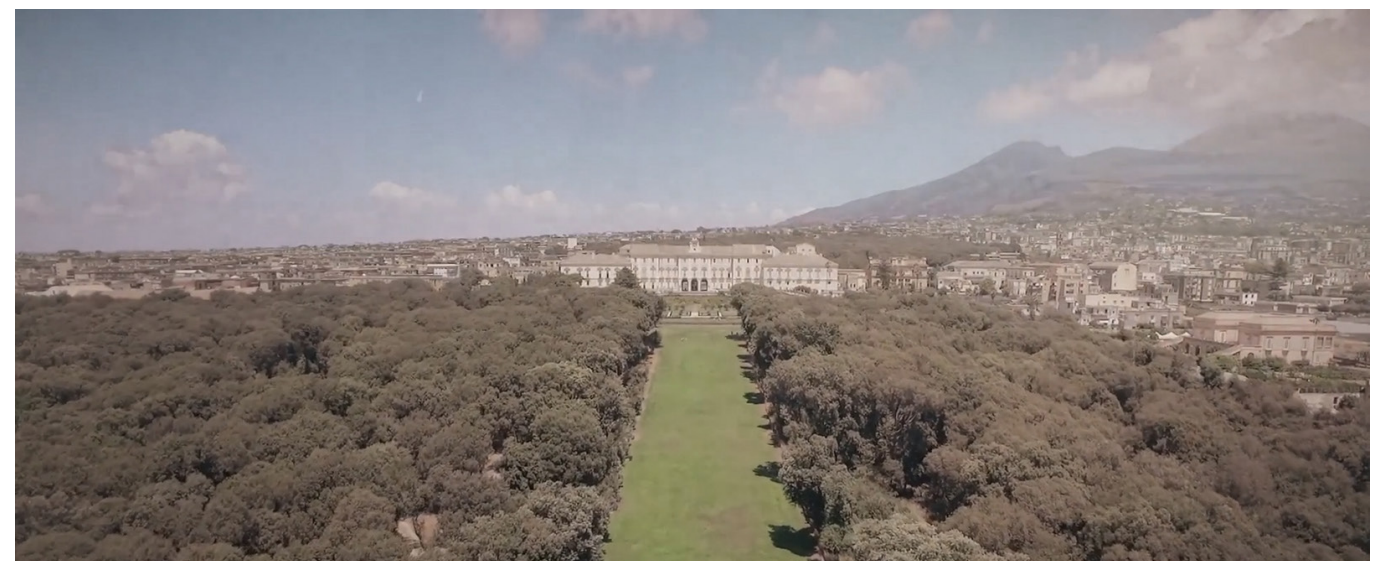




\section{Introduzione}

Negli ultimi anni, il tema della valorizzazione dei giardini Reali storici, connesso alle architetture dell'acqua, ha assunto una significativa attenzione da parte della comunità scientifica, soprattutto nel rispetto dell'attuale scenario internazionale di salvaguardia e valorizzazione del patrimonio paesaggistico. II cospicuo numero di studi sedimentati nel tempo, condotti in diversi settori disciplinari, solo raramente ha incontrato una rigorosa sistematizzazione del materiale storiografico, iconografico, grafico-tecnico ecc., definendosi quindi come inedito campo applicativo, che ha sostanziato, già da qualche anno, il dialogo in seno alla comunità scientifica internazionale dell'area della Rappresentazione [Papa et al. 2020, pp. | 36- |47] per mettere a punto un organico metodo di indagine e di gestione informativa - sia alla scala architettonica che a quella urbana e territoriale - capace, attraverso un utilizzo ragionato delle Tecnologie dell'Informazione e della Comunicazione, di offrire un agile modello digitale di conoscenza, analisi e disseminazione di questo importante e complesso patrimonio culturale, talvolta compromesso dall'incuria e dal degrado [Papa, D'Agostino 2020, pp. 25 I5-2532].

Riferendo questo primo ambito di indagine alle residenze Reali Campane [I], che come punti di una maglia a rete costituirono al tempo una vera e propria 'matrice dominante' intorno alla quale si è poi sviluppata l'attuale area metropolitana [Alisio 1980, pp. 72-85], ricopre un ruolo di singolare importanza il Real Sito di Portici che Carlo di Borbone, salito al trono del regno di Napoli nel 1735, fa costruire a partire dal 1738. Un sito reale dalle innegabili qualità paesaggistico-ambientali [Nocerino 1787], con un'ampia area verde (l'antico 'Bosco'), collocata in un contesto orografico atipico tra il complesso vulcanico del Sommo Vesuvio e la linea di costa che ha condizionato l'impianto complessivo della residenza reale fulcro del sistema delle Ville Vesuviane realizzate a cavallo della 'Strada Regia per le Calabrie' (fig. I) [Cazzato 20 I6, pp. 227-242].

Diverse e parziali le percezioni e fruizioni del Parco oggi che, caratterizzatosi nel tempo da integrazioni e cambiamenti conformativi, ha avuto momenti di abbandono e di lento recupero che sostanziano la definizione di un asset prototipale multiscalare, con la strutturazione di un modello relazionale e interdisciplinare (fig. 2), orientato alla fruizione web-reality based, attraverso cui rileggere - mediante sovrapposizioni, contaminazioni tra reale e virtuale [Ippoliti et. al. 2012, pp 45-54] - l'impianto planimetrico originario connesso al patrimonio idrico-infrastrutturale del 'bosco superiore ed inferiore' del Real Sito, recuperandone l'identità storico-culturale, nonché la dimensione figurativa e percettiva dei luoghi.

Fig. I. A sinistra, modello esemplificativo per la lettura del database Reali della Campania: destra, veduta aerea del complesso architettonico e paesaggistico del e paesaggistico del l'indicazione dell'antico traccione "Strico Regia per le Calabrie".
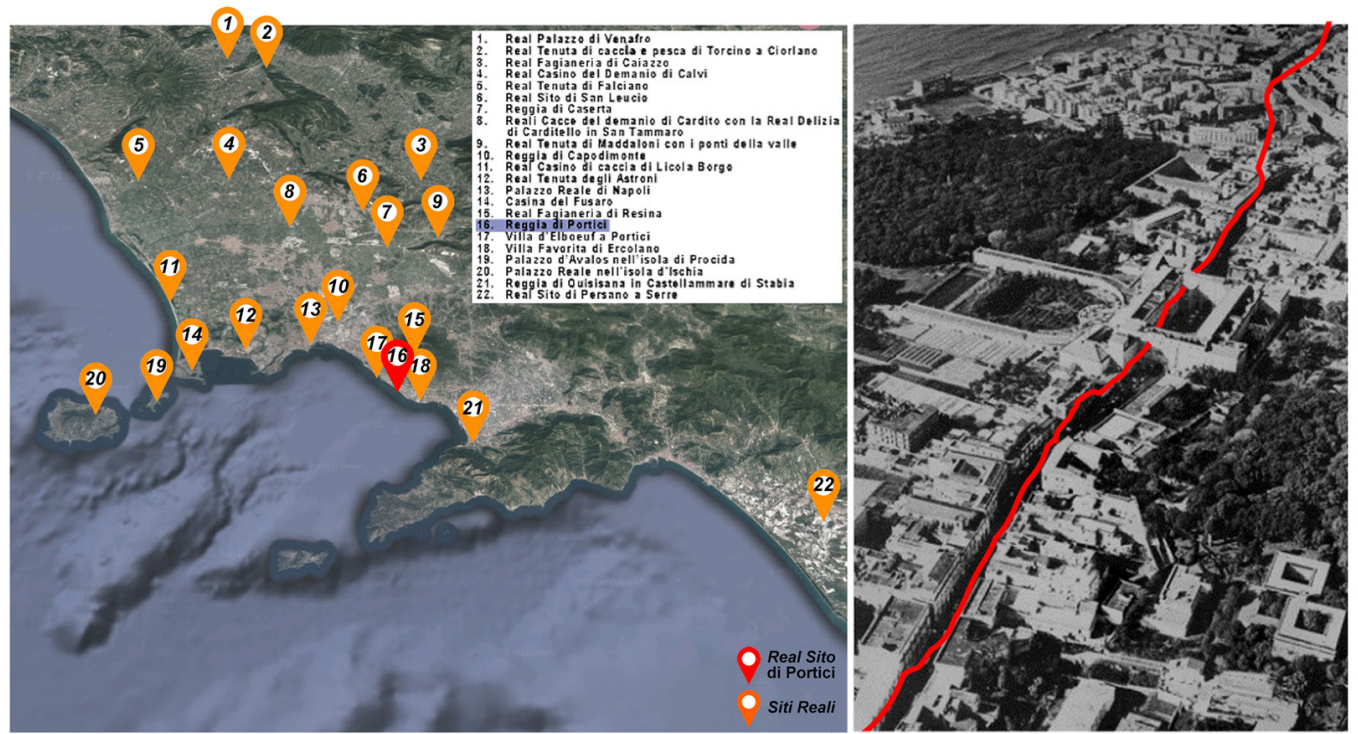


\section{Il complesso architettonico-paesaggistico del Real Sito di Portici}

La nuova dimora reale, voluta da Carlo nel comune di Portici per trascorrervi più o meno prolungati periodi di villeggiatura [Alisio 1959, pp. I27-191; De Cunzo 1959, pp. 86- 105], costituisce un episodio architettonico dal carattere 'enciclopedico', che ha visto operare vari architetti e ingegneri [2] in un progetto nato per aggregazioni successive e la cui evoluzione è difficile da documentare visivamente [Papa 2019, pp. 91-102]. È l'elemento naturalistico del complesso dispositivo spaziale del Parco, con i suoi aspetti particolarmente suggestivi, che contribuisce a dare valore al progetto dell'impianto e all'immagine degli spazi aperti esterni, che "Francesco Geri giardiniere maggiore inventò" [3] disegnando un pezzo significativo di territorio, tassellato da molteplici episodi architettonici che completano le funzioni del Real Sito; vengono inglobati con i loro giardini nel progetto alcuni episodi architettonici storici preesistenti come i contigui Palazzi Mascanbruno, Santobuono e Caramanico, nonché la più lontana Villa d'Elboeu, progettata da Ferdinando Sanfelice agli inizi del Settecento - ed acquistata dal Re alcuni anni dopo l'avvio della costruzione della Reggia - che diviene, assieme al forte e al porto del Granatello, il vero recapito architettonico a mare del Palazzo Reale [4]. Peraltro, le difficoltà realizzative legate alla presenza della Strada Regia, tra il giardino e i corpi già esistenti, il confrontarsi con un contesto orografico atipico, nonché i problemi di approvvigionamento delle acque occorrenti ai boschetti, alle fontane e alle peschiere [5], hanno determinato l'originale impianto dei giardini ed il peculiare carattere del sito.

Il parco, come testimonia la cartografia e liconografia storica, si inquadra in un complesso progetto in cui il tracciato dei sentieri, i giochi del terreno, della vegetazione e dell'acqua si impreziosisce da alcuni "frammenti di architettura che [...] aumentano ed esaltano oltre modo la bellezza naturale dei giardini" [D'Argenville 1709, cap. VII]; ne deriva un impianto nato dalla combinazione più o meno complessa di figure geometriche, in una figurazione la cui resa espressiva evidenzia la combinazione di architettura e studio topografico dei luoghi e guarda all'effetto "grato e bello all'occhio" prodotto dalla disposizione dei volumi, in una progettazione d'insieme del verde che favorisce "prati e boschetti di diversi arbori che per alcun tempo non perdon fronde" [Maltese 1967, pp. 245-246]; a ciò si aggiungono terrazze, loggiati, balconi (come la terrazza con tavolino del Re nel Giardino Segreto) con la funzione di rendere più leggibili da una quota più elevata gli spazi
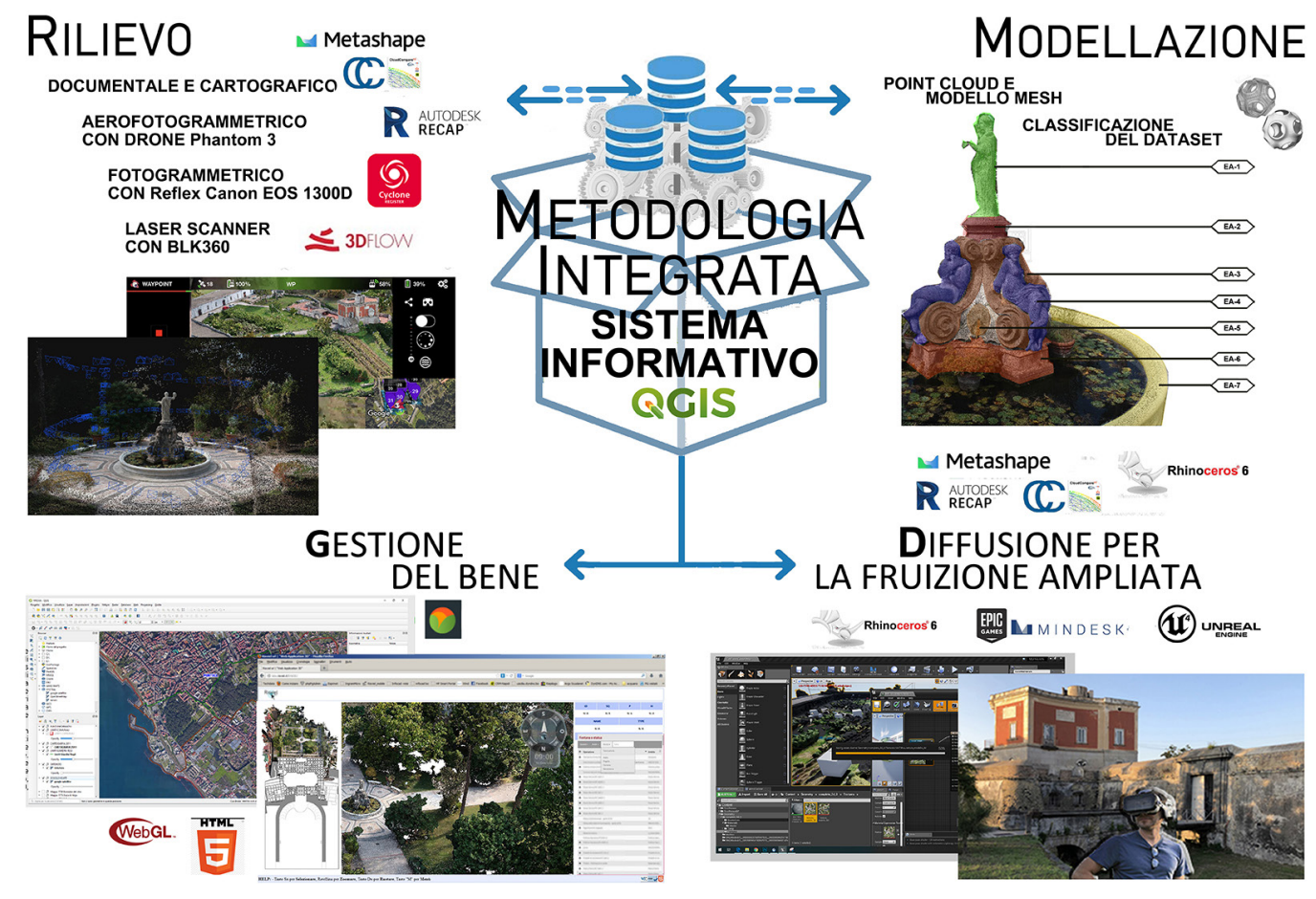
Fig. 3. Confronto con la veduta odierna della Vue du Jardin Royal de Porticy aux Environs de Naples, de $1780 \mathrm{ca}$

Fig. 4. Inquadramento urbano del Parco del Real Sito di Portici con la descrizione dell'originario impianto del 'Bosco superiore ed inferiore', rliedifici presenti al i775, limiti di Regi e l'indicazione di alcuni dei sistemi idrici sopravvissuta alle trasformazioni storiche.
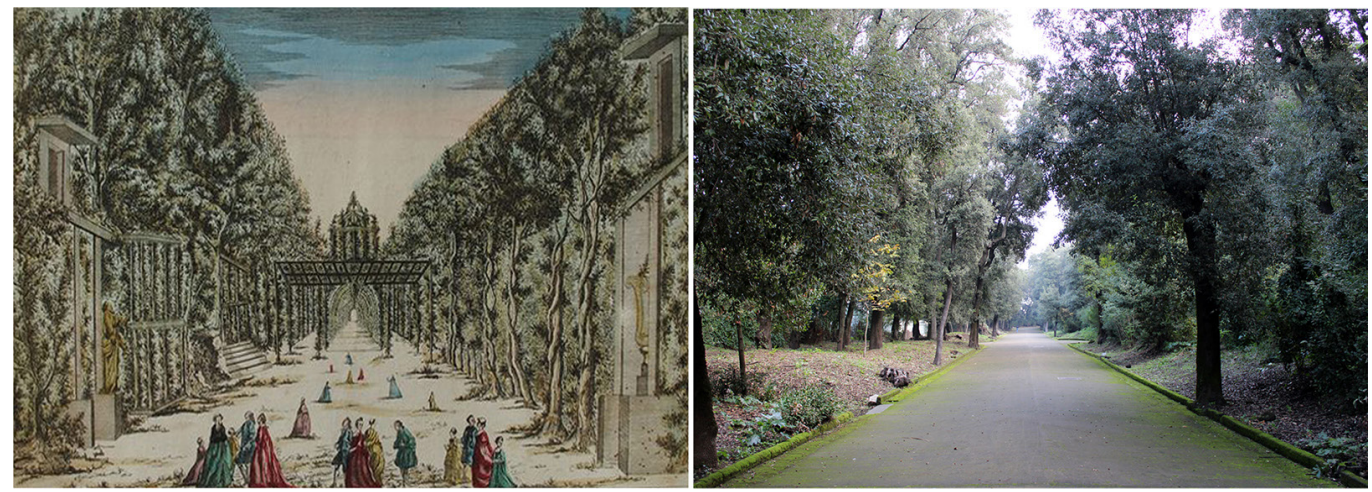

annessi circostanti. La costruzione di punti di vista nell'articolazione del progetto non aveva solo come scopo la generica fruizione del paesaggio naturale (il Vesuvio e il golfo), bensì la fruizione stessa delle ricche geometrie dei giardini (fig. 3).

Purtroppo oggi l'ampia area verde, incistata in un denso agglomerato urbano, appare gravemente alterata sia nella configurazione d'impianto originaria, dovuta alle diverse destinazioni d'uso che nel tempo si sono succedute, che per lo stato di abbandono in cui versano le sue architetture e le infrastrutture idriche. Un ambizioso progetto compromesso nell'assetto
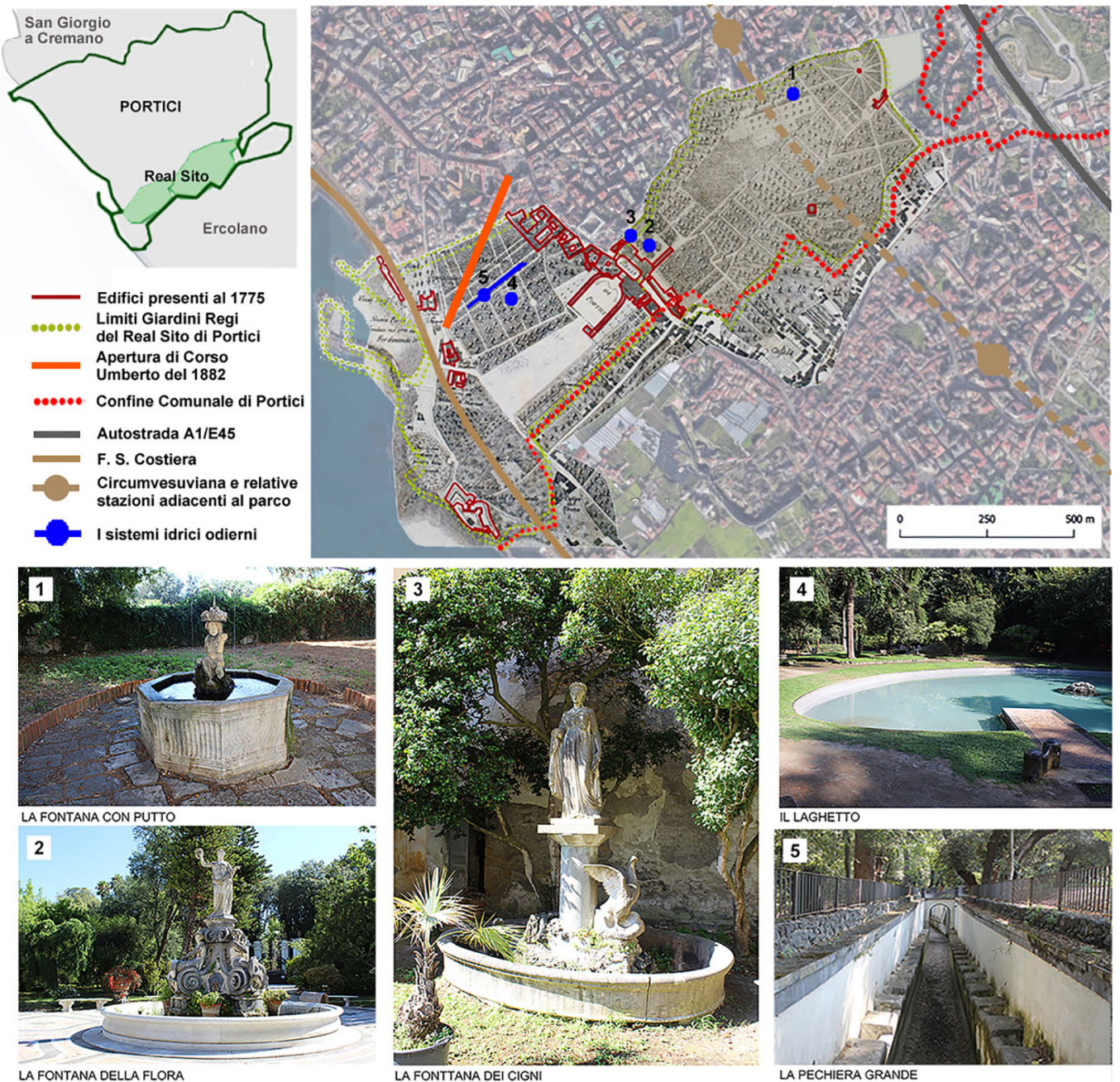

LA FONTANA DELLA FLORA

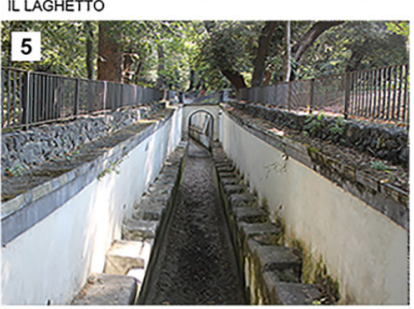


Fig. 5. Veduta delle soluzioni d'angolo della Fontana della Flora nell'Orto Botanico del rardino Buperiore del giardino superiore
Fig. 6. A sinistra, veduta dell'ingresso (da nordest), al Giardino Segreto nel "bosco superiore" del Real Sito di Portici. caratterizzato dalla

Fontana e della "Terrazza con tavolino del Re" (nella veduta di destra).
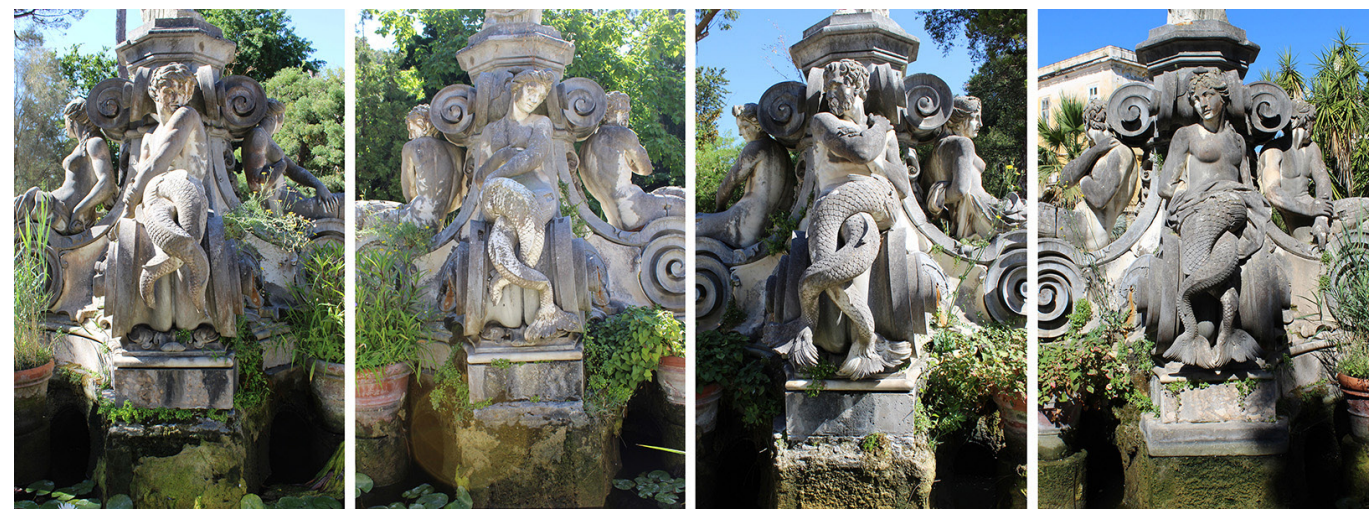

urbano consolidato prima con l'istituzione, nel I839, di una rete ferroviaria a servizio dell'intero Regno [Gamboni, Neri 1987; Pezza 2002] poi con la realizzazione, in età contemporanea, dell'autostrada, della Circumvesuviana e di Corso Umberto I, che hanno costituito uno dei motori della "elefantiasi urbana" [Vella 1996; Di Stefano, Trione 1979], avviando la saturazione dello spazio residenziale contermine, portando in secondo piano i caratteri edilizi e urbani storicamente improntati, senza determinare né nuove attribuzioni di senso, né un ridisegno organico della storica frammentarietà, che quei luoghi, da sempre, realizzano (fig. 4). II complesso sistema paesaggistico-architettonico conserva oggi ancora alcuni manufatti, sopravvissuti alle trasformazioni storiche, poco valorizzati sebbene di particolare valore storico-artistico e collegati al vasto patrimonio idrico infrastrutturale-ipogeo (figg. 5, 6), non ancora sistematicamente ed accuratamente esplorato. Ciò ha motivato lo sviluppo e l'ibridazione di un modello di conoscenza, gestione e disseminazione, disponibile all'interazione, utile a rivelare e valorizzare il paesaggio storico connesso alle architetture dell'acqua.

\section{Il sistema integrato di gestione e fruizione virtuale}

Secondo una metodologia ormai consolidata, che fa del rilievo e dell'indagine iconografica e cartografica storica gli strumenti privilegiati per restituire i processi di sviluppo e di modificazione del sito nel suo contesto urbano, lo studio ha favorito analisi diacroniche per ricostruire i processi di trasformazione dell'impianto generale ordinatore del Parco, particolarmente denso di variabilità conformativa sia nel disegno dei giardini che nelle connessioni col tessuto urbano circostante, ricucendo gli episodici spazi frammentari, talvolta degradati, ad un disegno preordinato unitario, 'visibile' nel rapporto con le strutture idriche del sottosuolo. Pertanto l'allestimento di una piattaforma interoperabile e multiscalare (City Model) - come database relazionale della componente grafico-vettoriale e storico-digitale - ha favorito la
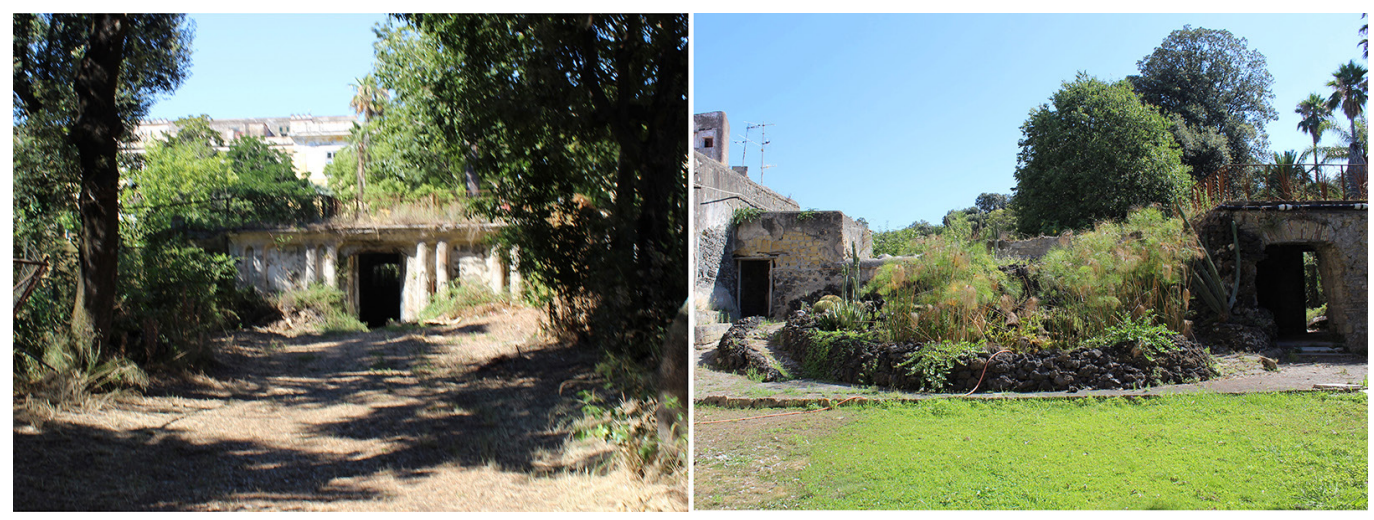
discretizzazione delle invarianti del sistema manufatti-giardini-tessuto urbano/agrario [Papa 20 I5], in un'organizzazione strutturale dei dati che consente, attraverso differenti percorsi/ scale di lettura, di rileggere l'originaria configurazione dei parterre, del bosco e della riserva di caccia, nonché l'uniformità o la diversità delle soluzioni d'impianto collegate al progetto della rete idrica che alimentava il sistema di fontane del parco.

A partire dalla Carta Tecnica vettoriale del Comune di Portici (nel sistema di riferimento WGS84 UTM 33N), sono state georeferenziati, attraverso il rubber-sheeting delle invarianti del sistema architettonico e paesaggistico in esame, i diversi documenti reperiti durante le fasi di studio [Papa et. al. 2020, pp. I36- I47], consentendo di rileggere capisaldi, matrici, morfologie e direttrici di sviluppo e trasformazione del sito (fig. 7). Dal confronto infatti del Documento di rilievo fatto realizzare dal re da Roque Joaquin de Alcubierre, del 1738-39, della Mappa del Duca di Noja, del 1775 e della Pianta generale del Sito in cui si contengono il Palazzo Reale di Portici e i giardini e boschetti dipendenti del giardiniere Francesco Geri, del I780, emerge un chiaro quadro su come è stata sviluppata la progettazione del Parco: riuso degli assi longitudinali preesistenti, disposizione dei viali laterali a spina di pesce, valorizzazione delle caratteristiche naturalistiche ed orografiche del terreno per soddisfare le esigenze di approvvigionamento idrico necessarie alla cura del verde e delle coltivazioni. La richiesta e il modello di riferimento è di un "Parterre a la Francesa" [6], con un'organizzazione planimetrica inseparabile sia da istanze d'ordine utilitaristico, sia da sottili motivazioni d'ordine ideale e radiocentrico (fig. 8). Ne deriva un'architettura di paesaggio, per cui l'impostazione geometrica traeva i propri strumenti dalla prospettiva, che prende "ordine da essa per la simmetria e grazia" [Nicèron 1636, p. I I], anche per apportare accorgimenti a difetti nella percezione proporzionale dovuti a qualche muro sghembo o a un falso angolo, procedendo ad "aggiustamenti" tramite quinte boscose addossate ai muri "per ingannare piacevolmente in virtù dell'estensione considerevole che così apparirebbe come recinto" [D'Argenville I7|3, p. 20]. Al verde strutturato ed antropico del giardino storico, si contrapponeva l'aspetto volutamente selvaggio del bosco circostante, collocato

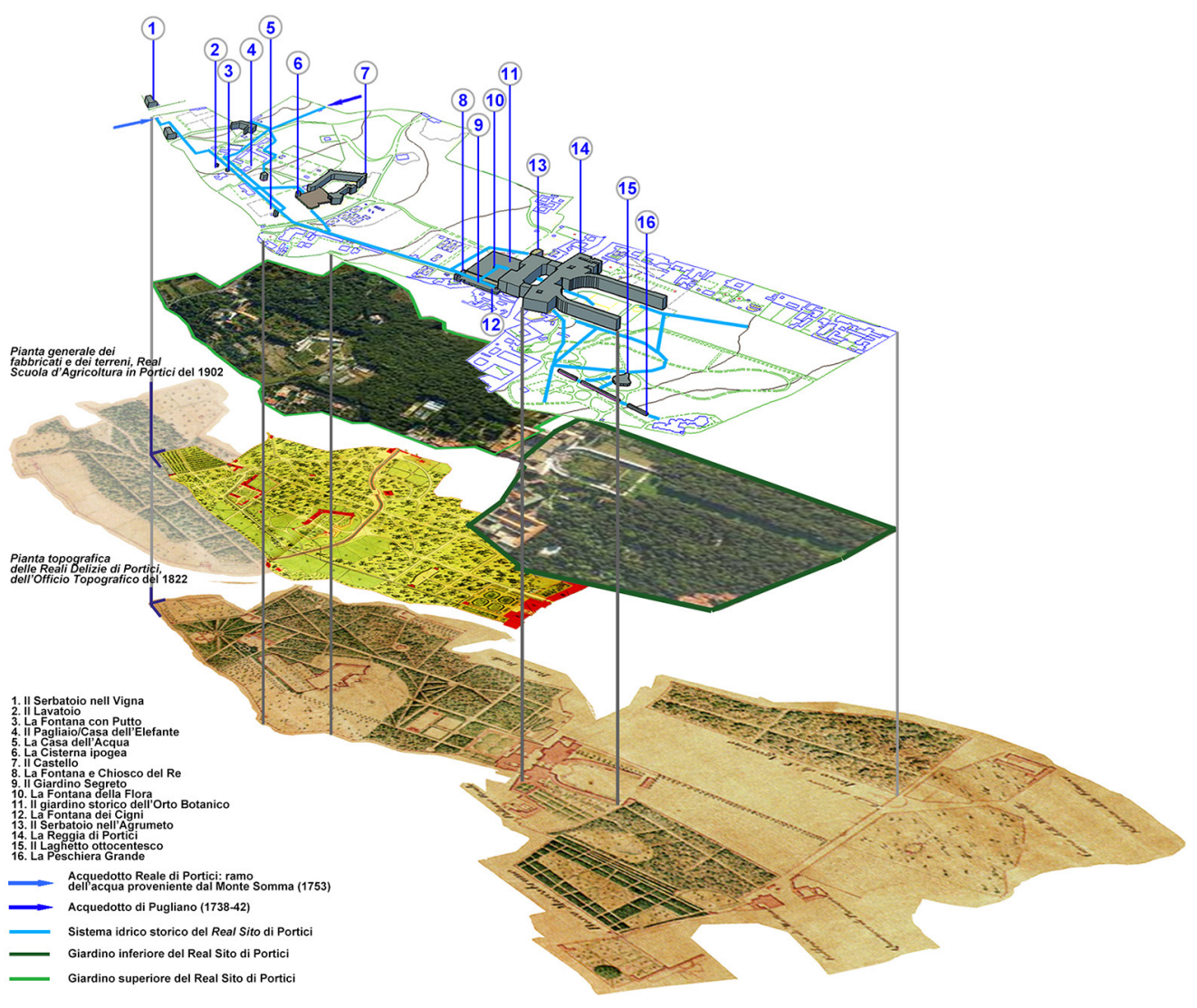


Fig. 8. A sinistra, Pianta generale del Sito in cui si contengono il Palazzo Reale di Portici e i giardini e boschetti dipendenti de giardiniere F. Geri, 1780 con l'evidenziazione dell'area oggetto della Pianta del Belvedere ne parco di Portici, firmata da Francesco Geri, 1780 e del progetto del Boschetto progetto del Boschetto di Portici, L Vanvitelli, di Portici, L. Vanvitelli, età del XVIII
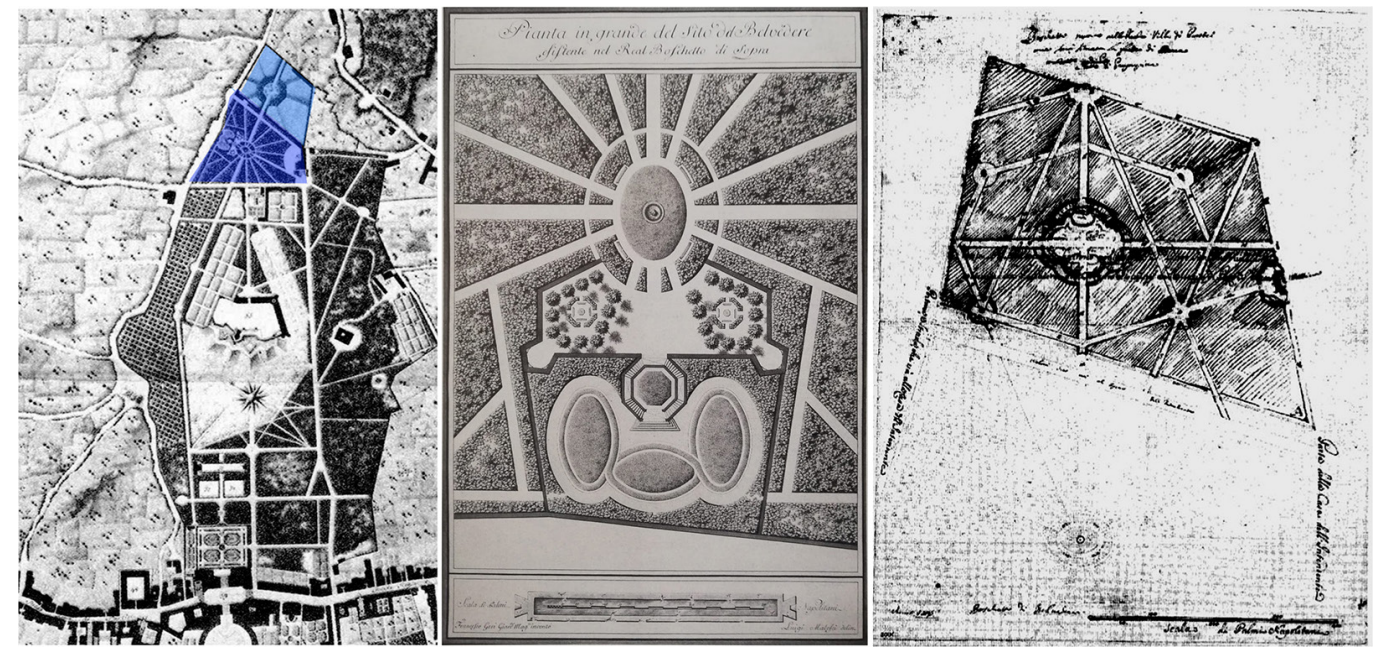

principalmente sul versante est. II progetto della rete idrica ha fatto da filo conduttore nel ripartire, secondo un ordine sistematico, le aree verdi, le colture specialistiche e gli ambienti di delizia, provvedendo ad un passaggio continuo tra il rigore formale delle aiuole e il bosco relativamente incolto, gratificando chi passeggia per la sorprendente apparizione di aree coltivate o aree in cui la fecondità delle forze della natura viene spesso raffigurata da grotte, fontane, divinità fluviali con giochi d'acqua che trasmettevano, visivamente e acusticamente attraverso il mormorio dei canali e lo scroscio delle fontane, una capacità ovidiana di trasformazione dello spazio. E in particolare la Pianta generale dei fabbricati e dei terreni della Real Scuola d'Agricoltura in Portici del 1906 ad evidenziare la preesistente rete idrico-ipogea, con sviluppo prevalentemente longitudinale lungo il versante ovest per Parco, e il collegamento ai diversi punti di attingimento quali le fontane, i pozzi, i serbatoi e le cisterne, tra cui quella più grande del Castello, l'elemento architettonico più rilevante del giardino superiore del Real Sito. In effetti proprio la cisterna del Castello, cavata nel banco di roccia vulcanica fino ad una quota di circa 6,5 metri ed alimentata da nord-ovest dal ramo idrico proveniente dall'Acquedotto Reale di Portici, rappresenta il fulcro del sistema di riserve idriche interrate del parco. La particolare artico-

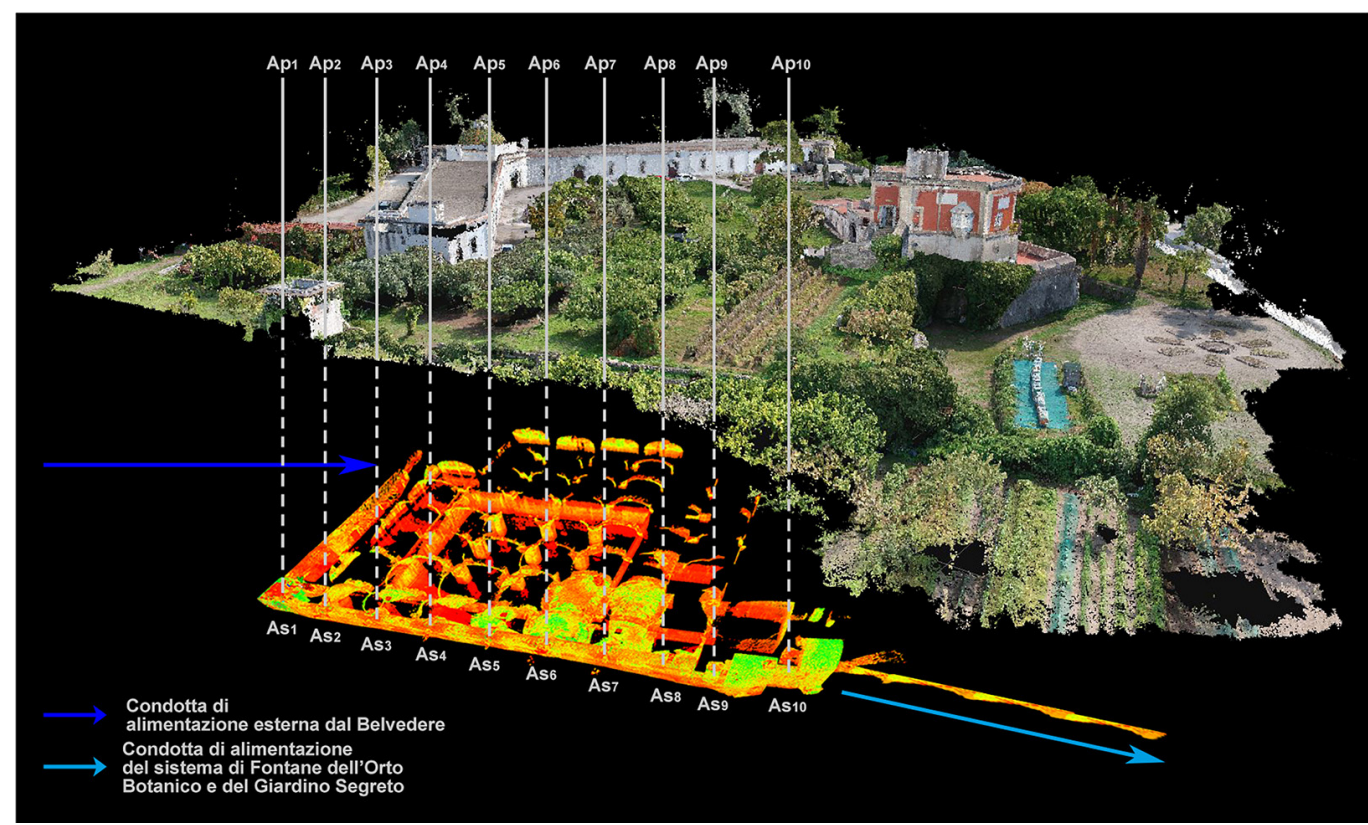

Fig. 9. Modello integrato dell'area del Castello e delle sue strutture di alimentazione idrica ipogee. 
lazione del complesso sistema ipogeo, in correlazione spaziale con le strutture in superficie attraverso il sistema di pozzi di ventilazione Asi-Api che si aprono sulla volta di copertura del condotto longitudinale per il controllo e la manutenzione della cisterna, ne ha suggerito l'approfondimento plano-altimetrico con attenzione anche al collegamento alla rete di adduzione ed alimentazione esterna (fig. 9).

Cosicchè per consentire una lettura simultanea dei molteplici rapporti pluridimensionali, la ricerca ha condotto alla costruzione di un modello unitario con la descrizione tridimensionale e di dettaglio del sistema idrico-antropico, collegato agli attributi del sistema informativo realizzato sulla base di una consolidata prassi metodologica di rilievo digitale (fig. 9) (laser scanner e fotogrammetria aerea e terreste) e rappresentazione integrata (indagine topografica per l'acquisizione dei Ground Control Point e rilevamento GPS/GLONASS per l'integrazione e la georeferenziazione delle informazioni spaziali, fornendo un modello in scala, relazionabile al Sistema Informativo di scala vasta) [Nex, Remondino 20 I4, pp. I- I5; Remondino 20 I I, pp. I I04- I | 38] capace di coniugare l'accuratezza geometrica con una efficace rappresentazione delle qualità dell'architettura indagata.

II modello informativo, quale "nucleo aggregativo" [Brusaporci 20।0], non si presta al solo processo di analisi della notevole mole di dati estremamente differenziati (testi, immagini, fotografie, grafici, etc.) - per rintracciare e comunicare le matrici morfologico-spaziali, le trasformazioni (ricostruzioni e/o decostruzioni) e il funzionamento nell'ampio sistema idrico -, ma costituisce un sistema aperto che, raccogliendo l'interazione di professionalità differenti, promuove il recupero e la gestione del bene. Ciopertanto uno degli obiettivi principali ha riguardato la progettazione di un'interfaccia user-friendly 3D web-based per garantire un accesso diretto al sistema, alle funzionalità di archiviazione e all'analisi dei dati, per divenire ad un riferimento unificato dell'informazione nell'ottica di una più efficace gestione del 'sistema parco' indirizzando, in ottica interdisciplinare, il progetto di conservazione degli elementi presenti e l'intero lifecycle del bene [Apollonio et. al. 2017, pp. 30-34], che include la sua conoscenza, fruizione, comunicazione e gestione [Benedetti et. al. 2008, pp. 275-290]. La trasposizione del sistema informativo in veste grafica HTML5, con libreria WebGL per quanto attiene la gestione e la visualizzazione dei dati 3D, ha richiesto una scomposizione e classificazione dei dataset, relazionando il city model GIS-oriented con i modelli e le rappresentazioni basate sulla frontiera (B-rep) o di tipo volumetrico, che tiene conto delle caratteristiche di forma e degli elementi costitutivi dell'opera. In particolare, il modello esemplificativo della Fontana della Flora è stato scomposto in modo da garantire anche un accesso per livelli e per componenti della vasca principale (EA-7), della parte basamentale (EA-6) e costitutiva degli elementi scultorei, come le sirene (AE-4) e le volute (AE-3), nonché della parte apicale (AE-2) con la statua della Flora (EA-I). Se da un lato ciò favorisce analisi tipologico-modulari, nonché approfondimenti sugli aspetti materici e di degrado - realizzando un "prototipo" reiterabile anche per le altre architetture dell'acqua dismesse e oggi in stato di abbandono - dall'altro tale approccio favorisce l'accesso alle informazioni anche ad un pubblico meno specializzato per rendere visibile (attraverso l'integrazione e la complementarità di tecniche e tecnologie di comunicazione diverse anche VR/AR) il rapporto tra le strutture del sottosuolo con quelle in superficie. In tale ottica il modello si configura come uno strumento di esplorazione, tanto tramite formati markup language di tipo descrittivo per definire applicazioni web-based linkate dal webGIS quanto in Unreal Engine, motore grafico utilizzato per la sperimentazione di realtà immersiva, nell'accessibilità ricettiva virtuale, e di rappresentazione e visualizzazione, tanto alla scala territoriale ed urbana quanto a quella di dettaglio, dei rapporti plano-altimetrici che si instaurano tra i diversi ambienti ipogei, ma soprattutto tra sopra e sotto (fig. 10).

\section{Conclusioni e sviluppi futuri}

Lo sviluppo di strumenti di modellazione avanzata e la loro interconnessione con piattaforme di visualizzazione web, a disposizione per un'utenza ampia e variegata, sta permettendo di testare modalità inedite di organizzazione e classificazione informativa per confrontarsi 
con scenari prodotti all'interno di ambienti digitali atti a creare mondi interattivi ideati non solo per mera finalità divulgativa. Questo quadro di classificazione dei modelli, con istanze semantiche ottimizzate, consente di ottenere pertanto modelli infografici, di supporto alla valorizzazione e migliore fruizione delle architetture di pregio storico in esame, che manifestano evidenti caratteristiche di flessibilità operativa quando riescono ad essere piegati alla necessaria richiesta di rigore metodologico, sfruttando un approccio che contempli l'uso sapiente dei processi di gestione informativa integrata.

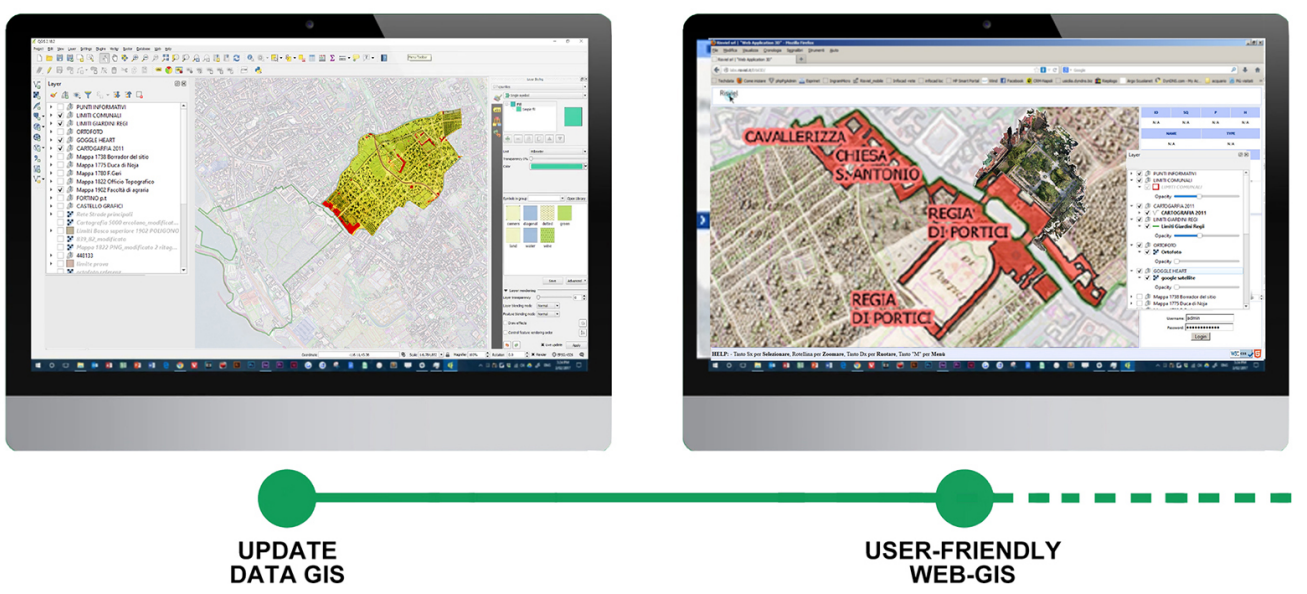

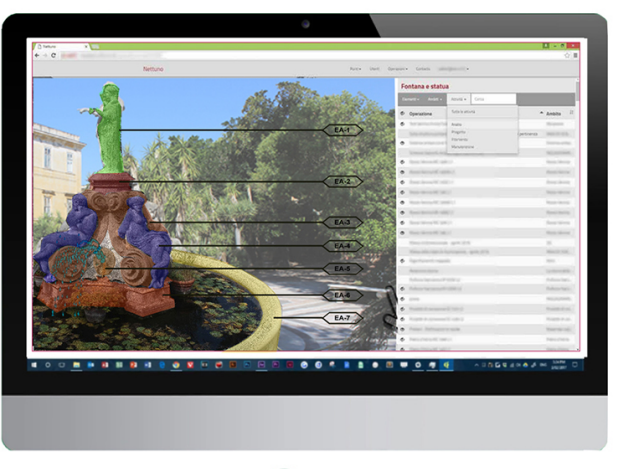

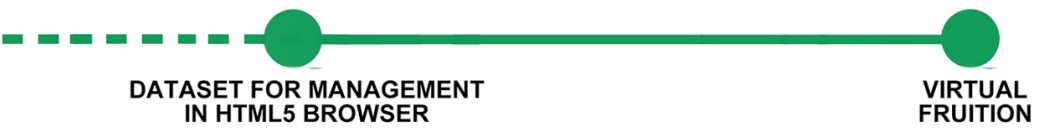

Note

[I] I Siti Reali e le Residenze Borboniche - diffusi in tutta l'estensione del Regno delle Due Sicilie ed in particolare nell'area metropolitana della Campania - costituirono un vero e proprio 'sistema territoriale di poli 'con funzioni museali, residenziali, venatorie, amministrative, agricole, industriali e di tutela del patrimonio ambientale [Alisio 1980, pp. 72-85].

[2] Hanno contribuito alla realizzazione principalmente Giovanni Antonio Medrano, Antonio Carnevari e Luigi Vanvitelli.

[3] Cfr. Piante generali ed altre particolari di alcuni Siti delle Reali Delizie di Portici presentate alla Real Maestà Sua dal Cav. D. Vespasiano Macedonio Intendente delle stesse Reali Delizie (Bibl. Naz. di Napoli - Collezione Palatina) e la lettera del 29 novembre del 1738 a "Ger Frnc.co faccia locchè se gli è comandato al giardino di Portici" (A.S.N. Casa Reale Amministrativa fasc. $1016 \mathrm{G}$.)

[4] Cfr. Relazione storica al PUC di Portici, 2012.

[5] Nelle fonti documentarie si ritrovano molte note relative ad opere di sistemazione delle acque, scavi e trasporti di terreno e rimozioni di pietre. Cfr. Real Villa di Portici e sue Reali Fabbriche, A.S.N. Casa Reale Amministrativa, fasc. I0 16, a. I739 e seg.

[6] In una lettera dell'I I marzo del 1739, il marchese di Salas scriveva a Medrano riguardo i disegni che questi aveva inviato con diverse aggiunte sul tipo di sistemazione delle fontane, statue e giochi d'acqua, così come a Versailles. Inoltre lo informava della decisione di orientare la fabbrica del palazzo reale in modo tale da far corrispondere la porta principale con la fontana centrale in asse con il giardino. 


\section{Riferimenti bibliografici}

Alisio G. (1959). Le ville di Portici. In Pane R. et al. (a cura di). Ville Vesuviane del Settecento. Napoli.

Alisio G. (1980). I Siti Reali. In Causa R. (a cura di). Civiltà del Settecento a Napoli (I 734- I 799). Firenze: Centro Di, pp. $72-85$.

Apollonio F.l. et. al. (20 I7). II restauro della fontana del Nettuno a Bologna. Un sistema 3D Web per la documentazione e la gestione dei dati. In Archeomatica, VIII-4.

Barbera F. (2006). Dalle ville nobiliari esoteriche al Palazzo Reale di Portici: il simbolismo del Sole e della Luna nella Santa Coppa. In Fagiolo M. (a cura di). Architettura e Massoneria. L'esoterismo della costruzione. Roma: Gangemi Editore.

Benedetti B. et al. (2008). Scientific knowledge and information representations in historical-technical archives of archaeological sites: Pompeii as a case study. In Responsibilities and opportunities in architectural conservation conference proceedings, $\mathrm{n}$. I.

Brusaporci S. (a cura di). (2010). Sistemi informativi integrati per la tutela, la conservazione e la valorizzazione del patrimonio architettonico e urbano. Roma: Gangemi Editore.

Cazzato V. (2016). Una "città di ville" alle falde del Vesuvio. In Giusti M.A. (a cura di). Ville lucchesi, d'Italia, del mondo. Lucca: Pacini Fazzi.

D'Argenville D. ( 1709). La thèorie et la pratique du jardinage. Cap.VII.

De Cunzo M. (1959). Le Ville Vesuviane. In Causa R. (a cura di). Civiltà del Settecento a Napoli (I 734- I 799). Firenze: Centro Di.

Di Stefano R., Trione A. (1979). II Miglio d'oro, itinerario fotografico attraverso le ville vesuviane di Pino Grimaldi. Napoli: II Laboratorio Edizioni.

Gamboni A., Neri P. (1987). Napoli-Portici. La prima ferrovia d'Italia: 1839. Napoli: Fausto Fiorentino Editrice.

Ippoliti E. et al. (2012). Interfacce e tecnologie visual 3D per conoscere, condividere e valorizzare il patrimonio culturale. Documentazione e Conservazione del Patrimonio Architettonico ed Urbano. In Disegnarecon, vol. 5, n. 10.

Maltese C. (a cura di). (1967). Francesco di Giorgio Martini. Trattati d'Architettura, ingegneria e arte militare. Milano: II Polifilo editore, vol. I.

Nex F., Remondino F. (20।4). UAV for 3D mapping applications: a review. In Applied Geomatics, n. 6.

Nicèron P. J. (1636). La perspective curiuse. Paris.

Nocerino N. (1787). La real villa di Portici. Napoli.

Papa L. M. (20I5). Cartografia e modelli di gestione dati. In Augenti N., Bontempi F. (a cura di). Ingegneria Forense. Crolli, affi dabilità strutturale e consolidamento. Palermo: Dario Flaccovio Editore.

Papa L. M. (2019). Considerations about Old Maps in the Digital Era. In The Representation of Landscape, Environment and Territory. Diségno, n. 5.

Papa L. M. et al. (2020). Un progetto di valorizzazione dei Siti Reali in Europa. II caso della Reggia di Portici in Campania. In Paesaggio Urbano, n. 2.

Papa L. M., D'Agostino P. (2020). Un processo integrato di conoscenza e visualizzazione. II castello della Reggia di Portici. In A. Arena et al. (a cura di). Connettere. Un disegno per annodare e tessere. Atti del $42^{\circ}$ Convegno Internazionale dei Docenti delle Discipline della Rappresentazione/Connecting. Drawing for weaving relationships. Proceedings of the 42th International Conference of Representation Disciplines Teachers, pp. 25 I5-2532. Milano: Franco Angeli.

Pezza V. (2002). La costa orientale di Napoli. Il progetto e la costruzione del disegno urbano. Napoli: Electa.

Remondino F. (20 I I). Heritage recording and 3D modeling with photogrammetry and 3D scanning. In Remote Sensing, vol. 3, n. 6.

Vella A. (1996). Trilogia della città vesuviana. In Quaderni vesuviani, n. 26.

\section{Autore}

Giuseppe Antuono, Università degli Studi di Napoli Federico II, giuseppe.antuono@unina.it

Per citare questo capitolo: Antuono Giuseppe (202 I). Sistemi e modelli integrati di conoscenza e visualizzazione. II 'Bosco' del Real Sito di Portici/ Integrated Systems and Knowledge and Visualisation Models. The 'Woods' of the Royal Site of Portici. In Arena A. Arena M. Mediati D. Raffa P. (a cura di) Connettere Un disegno per annodare e tessere Linguagoi Distanze Tecnologie Atti del $42^{\circ}$ Convegno Internazionale dei Docenti delle Discipline dello Rapprestazione/Conn Conference of Representation Disciplines Teachers. Milano: FrancoAngeli, pp. 1942-1961. 


\title{
Integrated Systems and Knowledge and Visualisation Models. The 'Woods' of the Royal Site of Portici
}

\author{
Giuseppe Antuono
}

\section{Abstract}

This paper will describe the successive results of an ongoing research inspired by a fruitful international discussion; the objective was to develop a system of management and enhancement of the vast landscape and architectural heritage of numerous (at times deteriorated) Royal Sites in the Mediterranean arranged according to a logical compositional order and interpreted through its crucial relationship with the design of water-related infrastructures in the Parks, for example little streams and ponds placed amongst the natural elements that create spectacular views and scenic areas. The Royal Site of Portici was chosen as a sample model; the goal was to clarify the interdisciplinary methodological approach employed in its design and also test the effectiveness and efficiency of integrated information tools -in line with the objectives of the sector of future and emerging technologies (FET), part of the EU Framework Programme for Research and Innovation 2020- used to reconstruct morphological-compositional relationships. The second goal was to create a broad relational database for the safeguard and recovery of the characteristic traits of the gardens/water-related architecture system which in the last few centuries has undergone radical alterations that have modified its figurative and perceptive dimension.

Keywords

cultural heritage, royal sites, integrated information systems, virtual model.

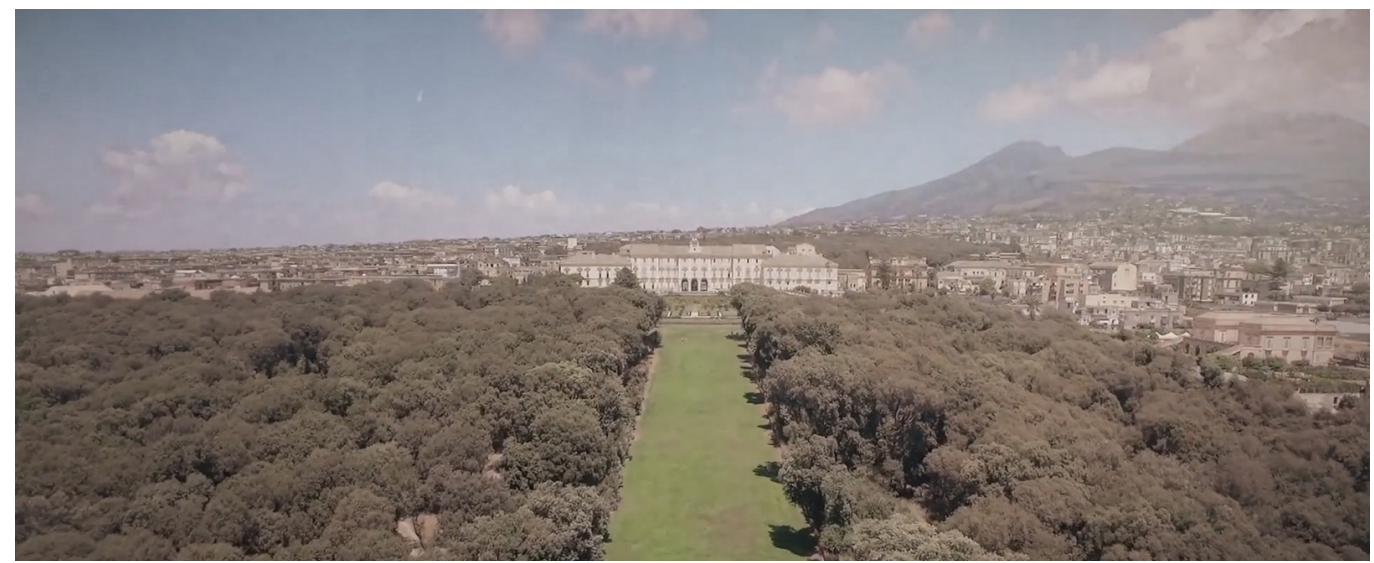




\section{Introduction}

In recent years the enhancement of historical, royal gardens surrounding water-related architectures has been an important issue for the scientific community, influenced in particular by the current international scenario regarding the protection and enhancement of landscape heritage. The numerous studies performed over the years in several disciplinary sectors have very rarely produced a meticulous systemisation of the historiographical, iconographic, graphic and technical material available. As a result this is a brand-new field of application that has, for some time now, fuelled an ongoing discussion in the international scientific community involved in Representation [Papa et. al. 2020, pp. |36-147] regarding the drafting of an organic study and data management method as regards architecture, urban planning and the territory. By sensibly exploiting Information and Communication Technologies, this method should be able to provide a streamlined digital model to understand, analyse and disseminate this important and complex cultural heritage, sometimes compromised by neglect and decline [Papa, D'Agostino 2020, pp. 25 I 5-2532].

This first field of study focuses on the Royal residences in the Campania region [I] which, like the points on a grid, created a 'main matrix' around which the current metropolitan area has developed [Alisio 1980, pp. 72-85]. The Royal Site of Portici plays a unique and important role in this grid; its construction began in 1738, commissioned by Charles of Bourbon after ascending to the throne of the Kingdom of Naples in 1735. The royal site, with its undeniable landscaping-environmental qualities [Nocerino 1787] and sprawling green area (the former "Woods"), is located in an unusual orographic position between the volcanic Sommo Vesuvio complex and the coast; its position has influenced the overall layout of the royal residence that acts as the hub of the Ville Vesuviane system straddling the 'Strada Regia per le Calabrie' (fig. I) [Cazzato 2016, pp. 227-242].

Today the Park can be seen and enjoyed only partially. Over the years additions and alterations have been made, but it has also experienced periods of abandonment and slow revival, making it a multiscalar prototype asset. A relational and interdisciplinary model (fig. 2) providing reality-based web fruition can be created using superimpositions and contaminations between reality and virtuality [lppoliti et. al. 2012, pp 45-54]; this will allow reinterpretation of the original planimetric layout of the water-related/ infrastructural heritage of the "upper and lower woods" of the Royal Site and establish not only its historical-cultural identity, but also the figurative and perceptive dimension of the area.

Fig. I. Left, model to assist in interpreting for the Royal Sites of the Campania region; right, aerial view of the architectural of the and lectural complex Royal Site of Portici, Royal Site of Portici, ndicating the old road Regia per le Calabrie'.
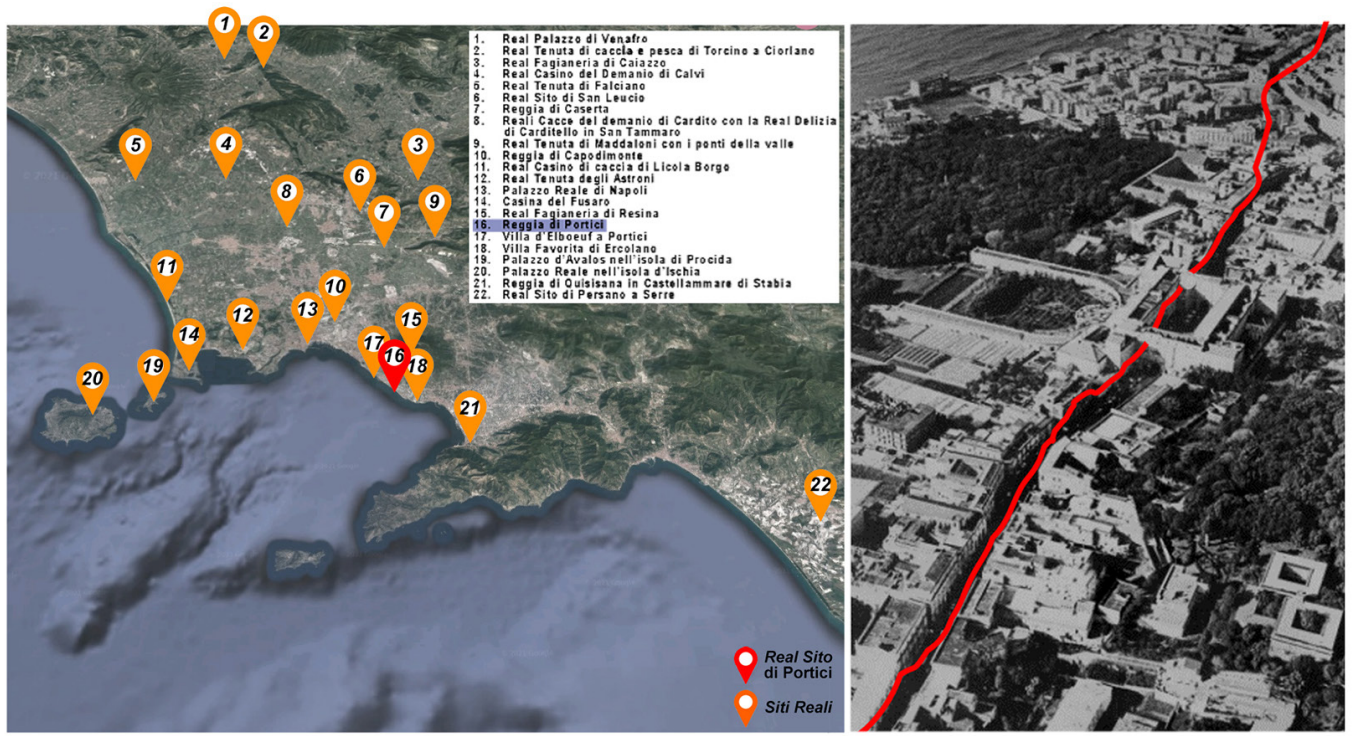


\section{The architectural-landscape complex of the Royal Site of Portici}

The new royal residence was commissioned by Charles in the Portici municipality so that he could spend more or less extended periods of time there [Alisio 1959, pp. I27-191; De Cunzo 1959, pp. 86-105]; it is an 'encyclopaedic' architecture in which several architects and engineers [2] were involved in a project that mushroomed over the years, with additions and alterations, thus making it difficult to visually document its evolution [Papa 2019, pp. 91-102].

The naturalistic element of the Park's complex spatial arrangement, with its particularly beautiful and attractive features, helps to enhance the layout and appearance of the outdoor spaces "invented by the head gardener Francesco Geri" [3] who designed a rather significant portion of the territory, dotted with multiple architectures that complete the functions of the Royal Site. Several pre-existing old buildings and their gardens were incorporated into the project; they include the nearby Palazzi Mascanbruno, Santobuono and Caramanico as well as Villa d'Elboeu (Further away) designed by Ferdinando Sanfelice in the early eighteenth century and bought by the King a few years after commencing construction of the palace. Together with the fort and port of Granatello, Villa d'Elboeu became the seaside outpost of the Royal Palace [4]. The original layout of the gardens and the unique nature of the site were, nevertheless, dictated by the difficulties associated with its construction due to the presence of the Royal Road between the garden and the existing buildings, the atypical orographic context, and the problem of how to supply the water needed for the small copses, fountains, and fisheries [5].

Maps and historical iconography reveal the park to be part of a complex project in which the paths, the contours of the land, its vegetation and water features are embellished by several "architectural fragments that [...] boost and truly enhance the natural beauty of the gardens" [D'Argenville 1709, chap. VII]. Its layout is the product of a more or less complex combination of geometric figures while its expressive figuration highlights the mix of architecture and topographical study of the site, achieving a "pleasing to the eye" effect created by the arrangement of the volumes. All this is part of an overall design of the green area enhanced by "lawns and small woods with different trees which for some time do not lose

RILIEVO

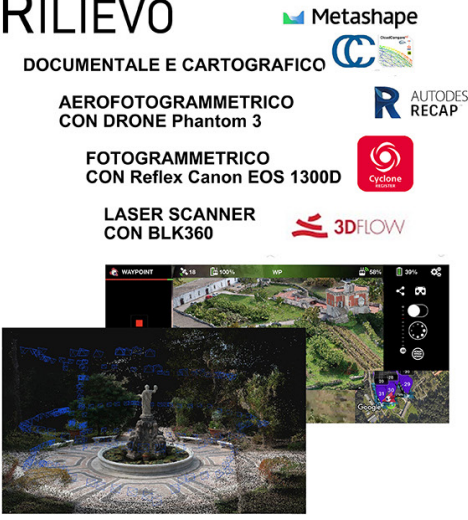

GESTIONE

DEL BENE

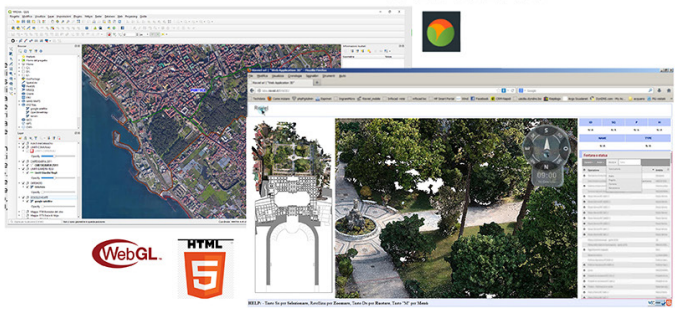

ModeLLAZIONE POINT CLOUDE

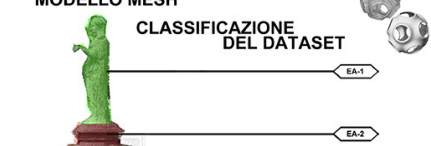

METODOLOGIA $\angle$ INTEGRATA SISTEMA INFORMATIVO QGIS

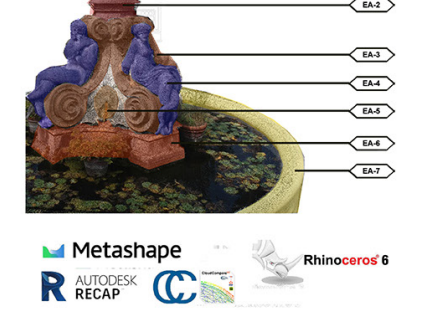

DIFFUSIONE PER LA FRUIZIONE AMPLIATA

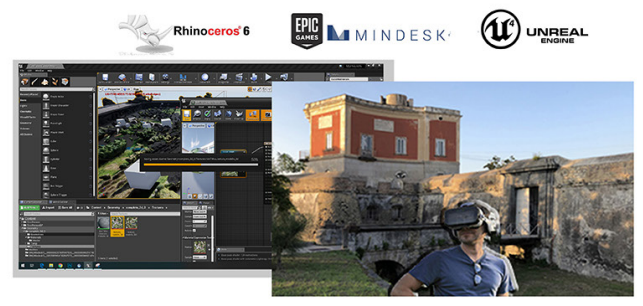


Fig. 3. Comparison between the Vue du Jardin Royal de Porticy aux

Environs de Naples, c. 1780 and (right) the same view
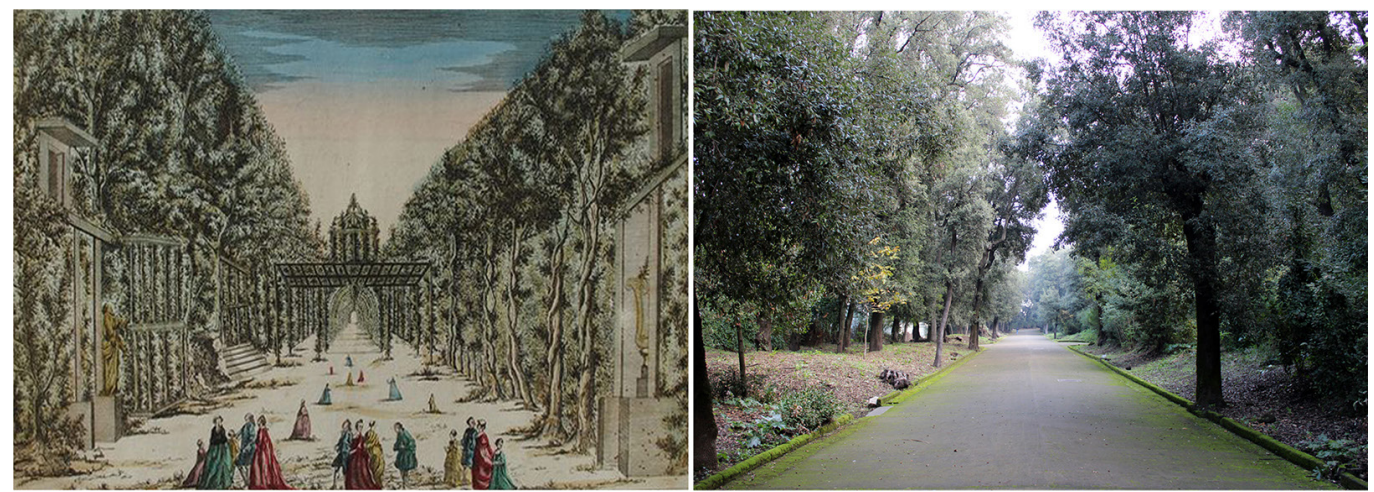

their foliage" [Maltese 1967, pp. 245-246]. There are also terraces, loggias, and balconies (e.g., the terrace with the King's small table in the Secret Garden) so that the surrounding areas could be seen and appreciated more easily. Establishing viewpoints in the multifaceted project was a ruse to not only be able to generically enjoy the natural landscape (Vesuvius and the Gulf), but also the intricate geometries of the gardens (fig. 3).

Sadly, the original layout of the sprawling green area, imprisoned in a dense urban agglomeration, has been critically modified not only due to its different uses over the years, but
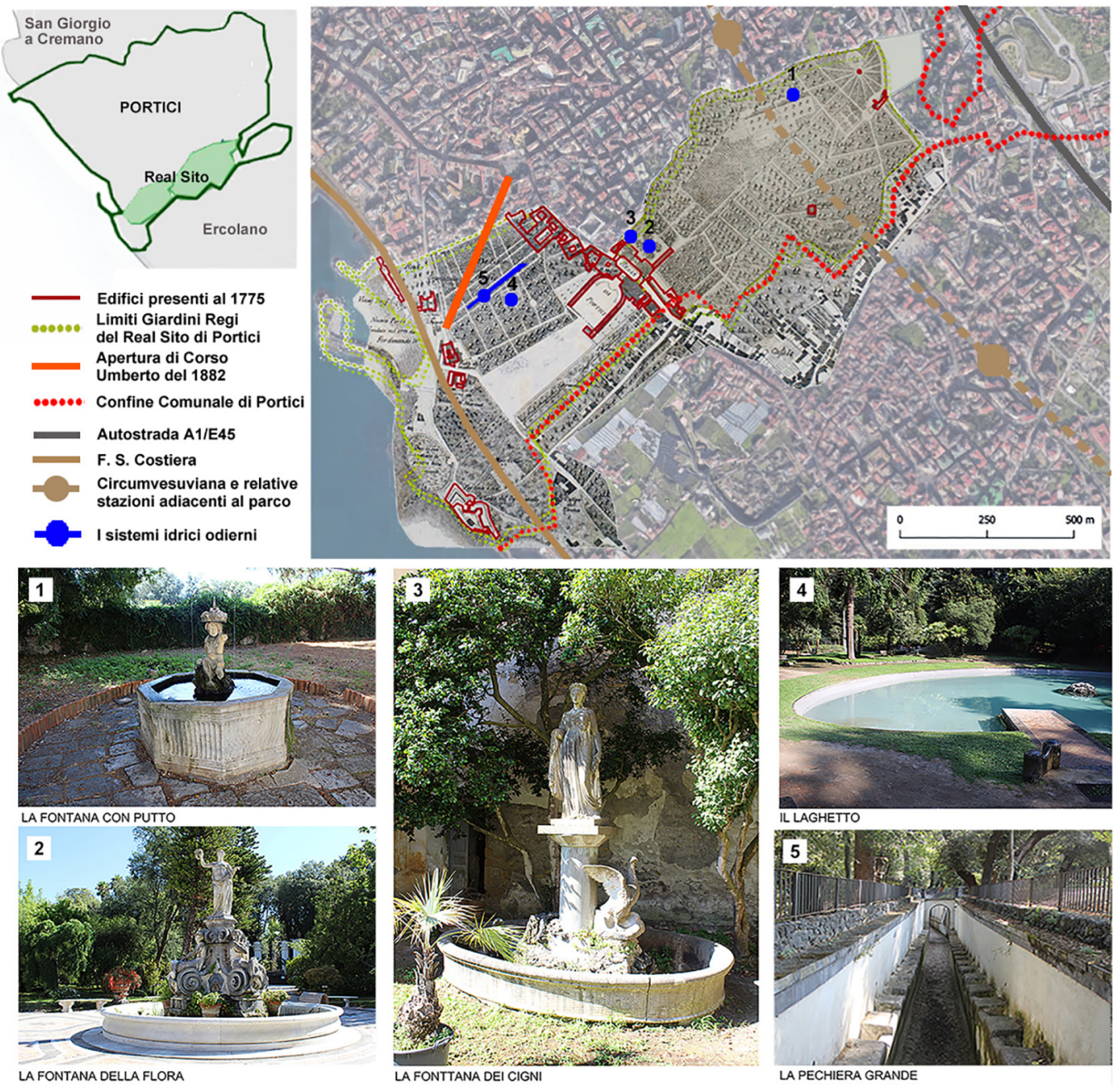

LA FONTANA DELLA FLORA

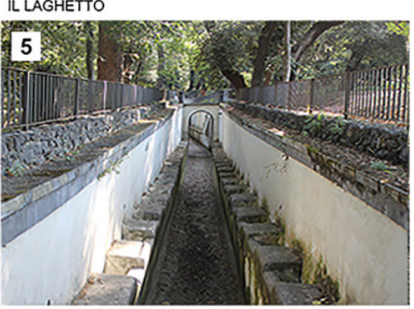


Fig. 5. The corner solutions of the Fountain of the Flora in the Botanical Gardens garden of the Royal Site of Portici.
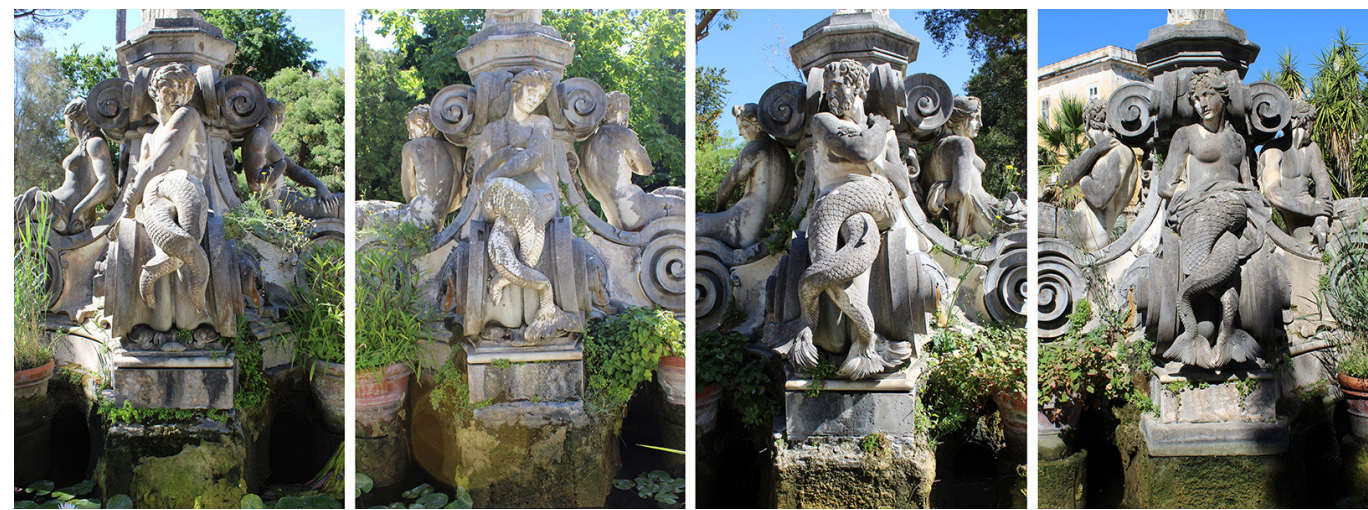

also because its architectures and water-related infrastructures are in a state of neglect and abandonment. The ambitious project was compromised in the urban context due to the creation of a railway system ( 1839 ) running throughout the Kingdom [Gamboni, Neri 1987; Pezza 2002], and then by the modern construction of the motorway, the Circumvesuviana, and Corso Umberti I. These infrastructures were some of the reasons for this "urban elephantiasis" [Vella 1996; Di Stefano, Trione 1979], saturating the adjacent residential space and placing the historically-oriented features of the buildings and urban environment on the back burner, but without creating new meanings or providing an organic redesign of the historical fragmentation that has always characterised this area (fig. 4).

The complex architectural-landscape system still contains several buildings that have survived the transformations implemented over the years; although they are not as appreciated as they should be, they are historically and artistically important and are part of the vast infrastructural-underground water-related heritage (figs. 5, 6), not yet thoroughly and systematically explored. This has prompted the development and hybridisation of an interactive, knowledge-gathering, management and dissemination model to reveal and enhance the historical landscape linked to water-related architectures.

\section{The integrated management and virtual fruition system}

Based on the now consolidated methodology that employs surveying and historical iconographic and cartographic research as privileged tools, diachronic analyses were performed to reconstruct the transformation of the overall plan of the Park, chiefly full of conformational variability in both the design of the gardens and its links with the surrounding urban fabric. This was achieved by linking the episodic fragmented and sometimes deteriorated spaces to a unitary, pre-established design 'visible' in its relationship with the water-related structures underground.
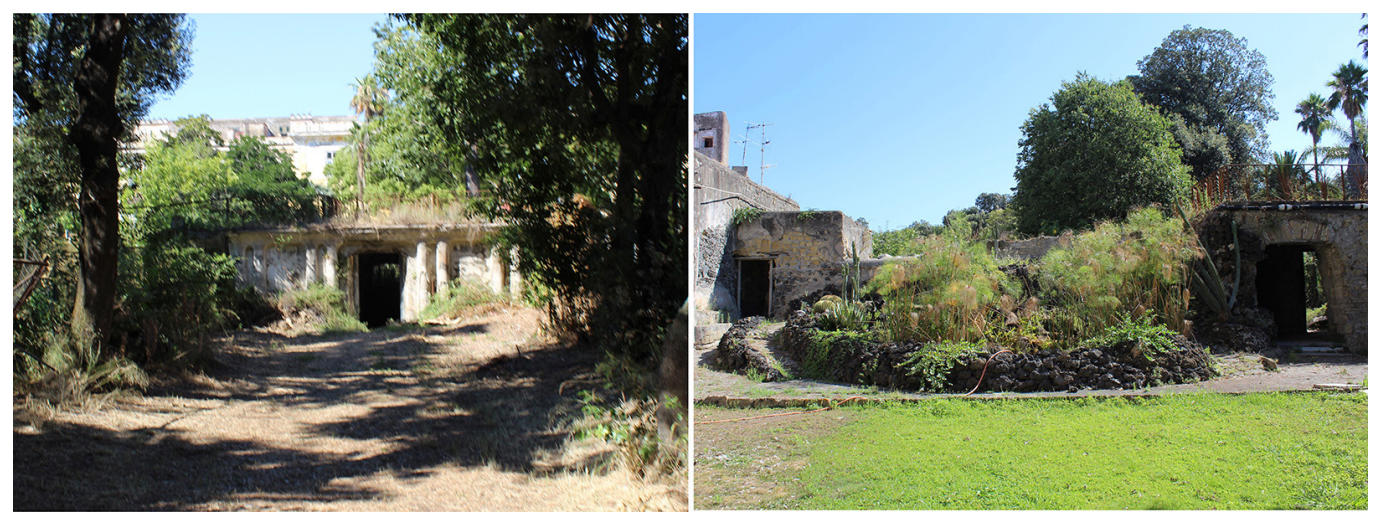

Fig. 6. Left, the entrance (from the north-east) to the Secret Garden the Royal Site of Portici, with the Fountain and "Terrace with the King's table" (in the image to the right). 
The creation of an interoperable, multiscalar platform (City Model) -as a relational database of the graphic-vectorial and historical-digital component- facilitated the discretisation of the invariants of the buildings-gardens-urban/agrarian fabric [Papa 20I5], in a structural organisation of the data which, using different paths/interpretative scales, permitted reinterpretation of the original configuration of the parterre, woods, and game reserve as well as the uniformity or diversity of the layout solutions linked to the design of the network supplying water to the fountains in the park.

The documents gathered during the study phase [Papa et. al. 2020, pp. 136-147] were georeferenced by rubber-sheeting the invariants of the architectural and landscape system in question. This operation, that exploited the Vectorial Technical Map of the Municipality of Portici (in the reference system WGS84 UTM 33N), allowed us to reinterpret the mainstays, matrixes, morphologies, and directions in which the site was developed and transformed (fig. 7).

In fact, a comparison between the Survey Document the King commissioned Roque Joaquin de Alcubierre (1738-39), the Map by the Duke of Noja (1775), and the General Plan of the Site with the Royal Palace in Portici and the gardens and small woods for which the gardener Francesco Geri is responsible ( 1780), clearly shows how the design of the Park was developed: reuse of the pre-existing longitudinal axes; arrangement of the side avenues in a herringbone pattern; enhancement of the naturalistic and orographic characteristics of the terrain so as to supply the water needed by the plants and farming activities. The request and reference model specified a "French Parterre" [6]; the plan had to combine utilitarian requirements and subtle idealistic and radio-centric patterns (fig. 8). The outcome was a landscape architecture -the geometric motif was inspired by perspective- that obtains "order from it to create symmetry and grace" [Nicèron 1636, p. II] as well as make a few changes to problems in the proportional perspective due to a few crooked walls or false corners. The solution was to make "adjustments" by creating woody backdrops next to the walls "to pleasingly deceive by

Fig. 7. Summary diagram of the Information georeferencing of georeferencing of layering of the layout layering of the layout of the underground infrastructures supplying wands and rivers in the 'upper and lower woods'.

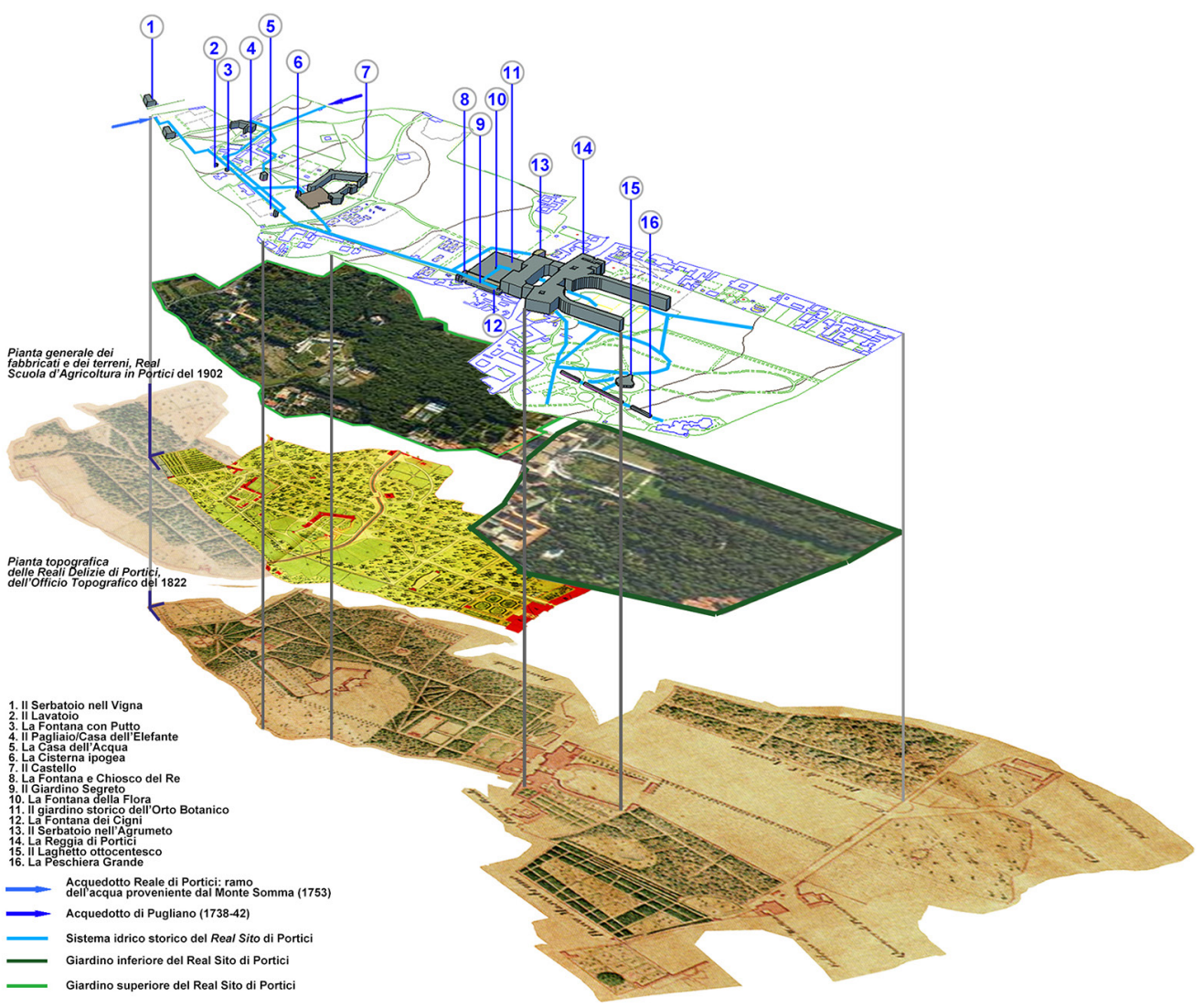


Fig. 8. Left, General Plan of the Site with the Roya Palace in Portici and the gardens and small woods or which the gardener Geri is responsible, 1780 Centre, images showing the area of the Plan of the Belvedere in the park in Portici, designed by Francesco Geri, 1780. Right, the design of the New Woods in the Royal Villa in Portici, L. Vanvitelli, econd half of the eighteenth century.
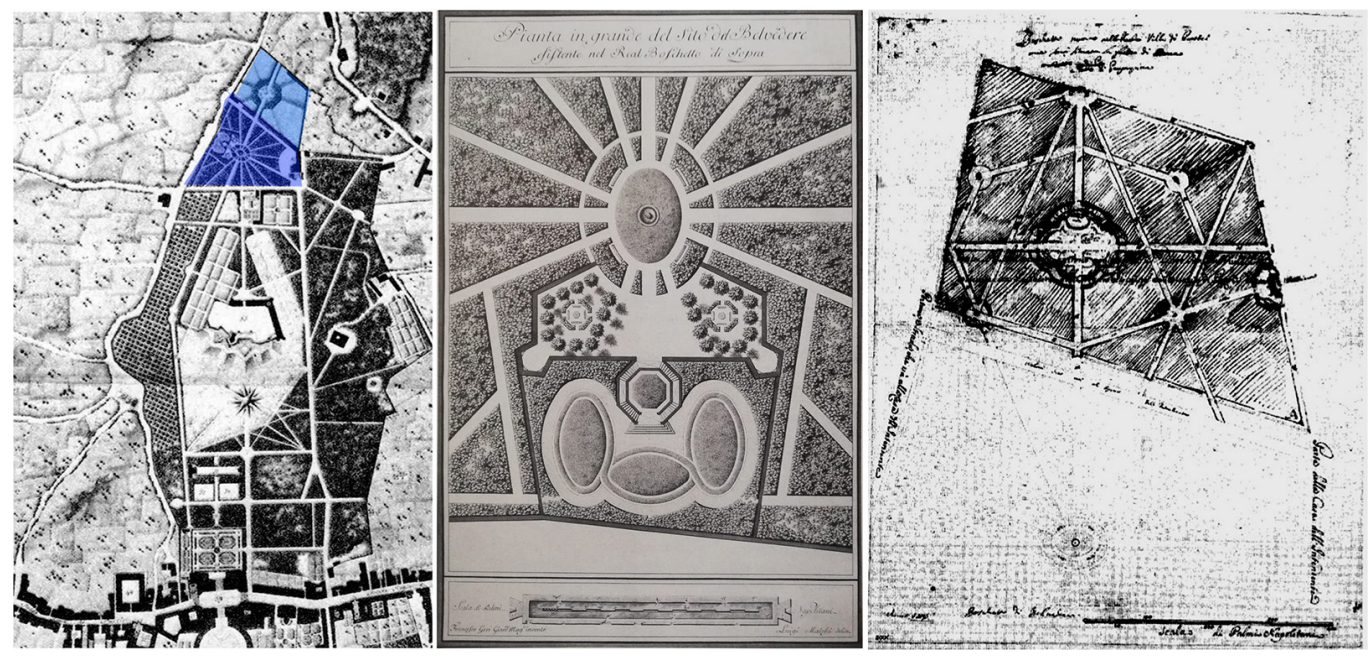

virtue of their considerable width and thus appear as a fence" [D'Argenville 17|3, p.20]. The structured and anthropic vegetation of the old garden was juxtaposed against the deliberately wild woods around it, positioned mainly to the east. The design of the water network was used to systematically separate and position the green areas, specialty crops and pleasure areas; a seamless link was established between the formal rigidity of the flowerbeds and the relatively unkempt woodland, rewarding walkers with amazing views of cultivated areas or areas in which the lushness of the forces of nature is represented by grottoes, fountains, river gods and water features that visually and acoustically convey -thanks to the murmuring of the canals and the gushing of the fountains- an Ovid-style ability to transform space. In particular, the General Plan of the buildings and lands of the Royal School of Agriculture in Portici in 1906 highlights the pre-existing underground water network along a chiefly longitudinal path bordering the west side of the Park as well as the connection between the various points where water was pumped to the fountains, wells, tanks and cisterns, including the biggest cistern supplying the Castle - the most important element in the upper garden of the Royal Site. The cistern of the Castle is the hub of the underground water reserve of the park; it

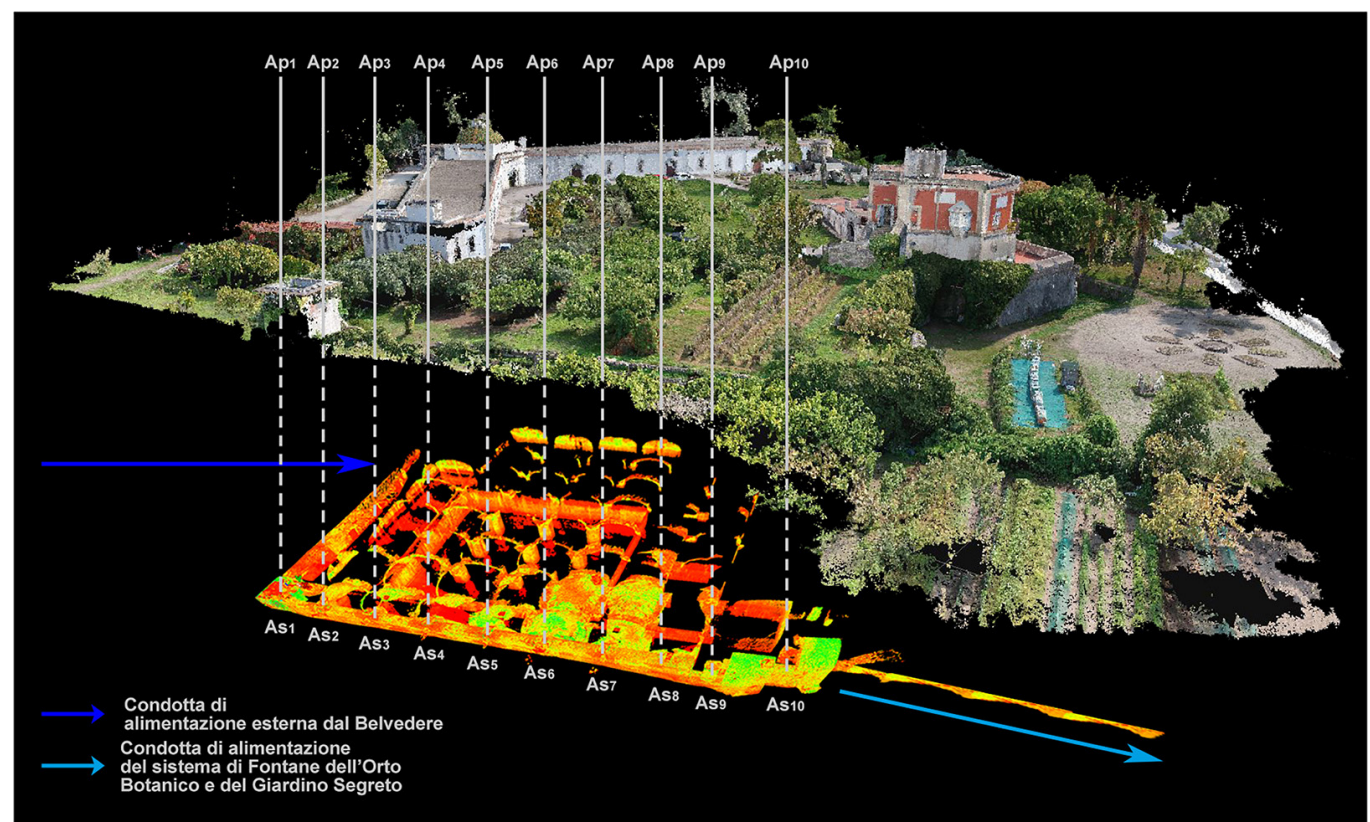

Fig. 9. Integrated model of the area of the Cast water supply network 
was dug out of a volcanic rock bed down to a depth of roughly 6.5 metres and is supplied with water from the north-west by a conduit from the Royal Aqueduct in Portici. The rather unique and complex underground system is spatially linked to the above ground structures by the network of Asi-Api ventilation wells located on the vault of the longitudinal conduit so that the cistern can be inspected and maintained. This situation prompted a careful, in-depth planimetric and altimetric study, particularly on the link between the water supply network and the network outside the park (fig. 9).

To simultaneously interpret the many multidimensional relationships, a model was built with a three-dimensional, detailed description of the anthropic water supply network linked to the features of the information system created using a consolidated digital survey method (fig. 9) (laser scanner and aerial and terrestrial photogrammetry) and an integrated representation capable of merging geometric accuracy with an effective representation of the features of the architecture in question (topographic study to acquire the Ground Control Points and a GPS/GLONASS survey for the integration and georeferencing of the spatial data that provided a scale model, relatable to the vast scale Information System) [Nex, Remondino 20 I4, pp. I- I5; Remondino 20 I I, pp. I I04- I I 38].

The information model, functioning as an "aggregative nucleus" [Brusaporci 20I0], can be used to analyse the large amount of very different data (texts, images, photographs, drawings, etc.) in order to identify and convey the morphological-spatial matrices, transformations (reconstructions and/or deconstructions), and the functioning of the vast water supply. However it is also an open system that enables the asset to be recovered and managed by all kinds of professionals. This is why one of the main objectives of the study was to design a user-friendly 3D web-based interface to ensure direct access to the system and archival and data analysis functions; the model will be a single data reference point ensuring efficient management of the "park system". From an interdisciplinary point of view it will input into the proposed conservation of the elements present and its entire lifecycle [Apollonio et. al. 2017 , pp. 30-34]; it will include knowledge about the asset and its fruition, communication and management [Benedetti et. al. 2008, pp. 275-290].

The transposition of the information system into HTML5 graphics, with a WebGL library, involving the management and visualisation of the 3D data, required a breakdown and classification of the dataset, linking the GIS-oriented city model with the models and representations based on the boundary (B-rep) or volumetric, that take into account the form and elements of the work in question. In particular, the model of the Fountain of the Flora was broken down in order to ensure access according to the levels and components of the main basin (EA-7), the base (EA-6) of the sculptural elements, for example the sirens (AE-4) and volutes (AE-3), and the upper part (AE-2) with the statue of the Flora (EA-I).

On the one hand this facilitates a typological-modular analysis and in-depth study of the material aspects and deterioration by creating a 'prototype' that can be repeated for the other water-related architectures currently abandoned and no longer in use. On the other, it also enhances access to the information by a less specialised public and helps clarify the relationship between the underground and above ground structures (thanks to the integration and complementarity of the different communication techniques and technologies, including VR $A R$ ). Bearing this in mind, the model is an exploration tool, using either descriptive markup language formats to define web-based applications linked by the webGIS or Unreal Engine, a graphic engine used to test immersive reality, in virtual receptive accessibility, and representation and visualisation, at territorial, urban, and detailed level, of the planimetric and altimetric relationships established between the underground environments, but especially between above and below ground (fig. 10).

\section{Conclusions and future developments}

The creation of advanced modelling tools and their interconnection with web visualisation platforms -available to a broad and varied public- makes it possible to test unusual data organisation and classification methods and compare them against scenarios produced in 
digital environments so as to create ideal interactive worlds for more than just dissemination purposes. This classification of the models with optimised semantics enables the creation of infographic models to support the enhancement and improved fruition of these valuable old architectures; the models are operationally flexible when they can be adapted to the request for methodological rigour by exploiting an approach involving the skilful use of integrated data management processes.

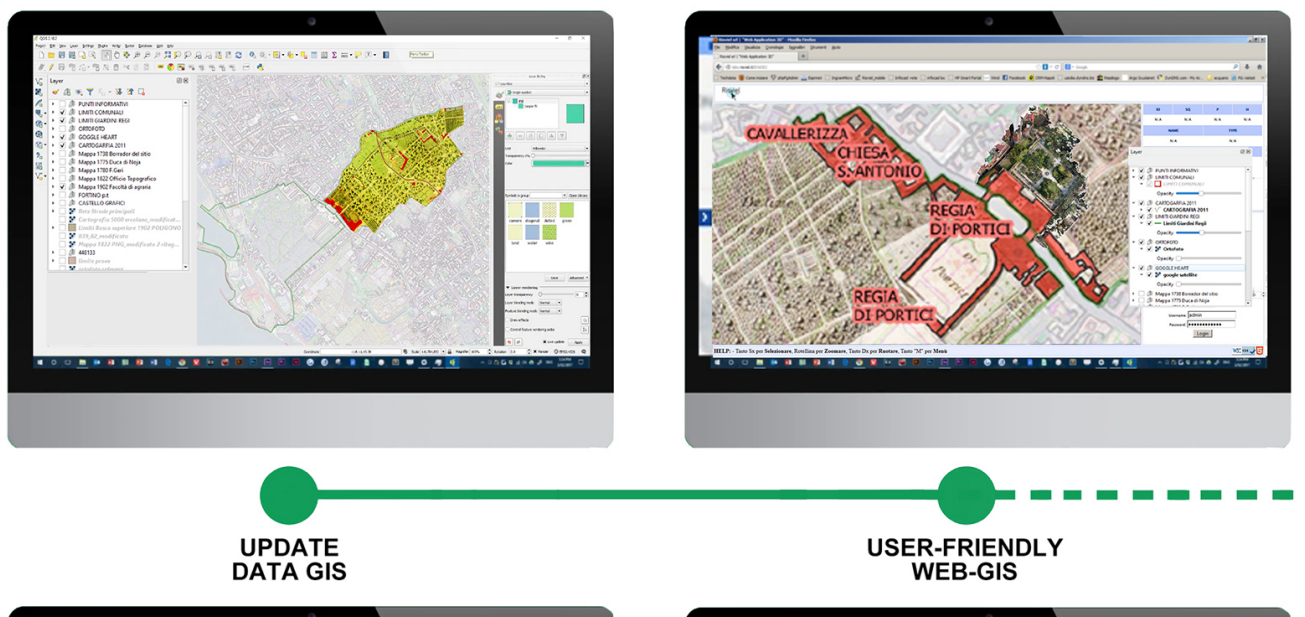

Fig. 10. The integrated model: from the information system to implementation of the model to manage and provide broade frition provide broader fruition Site in Portici.

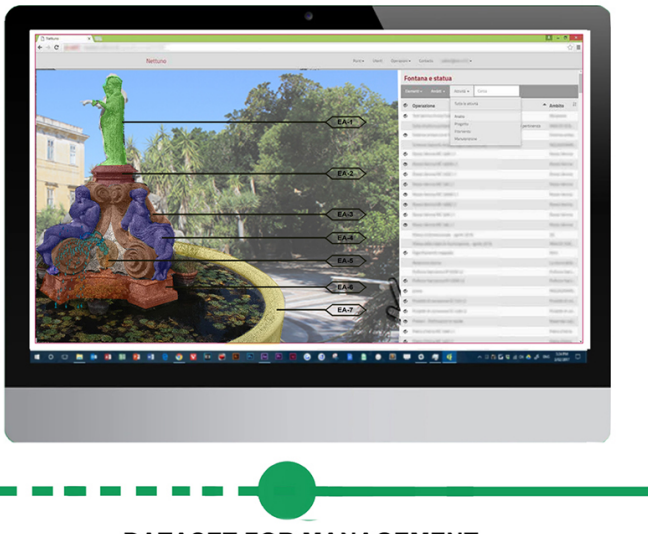

DATASET FOR MANAGEMENT IN HTML5 BROWSER

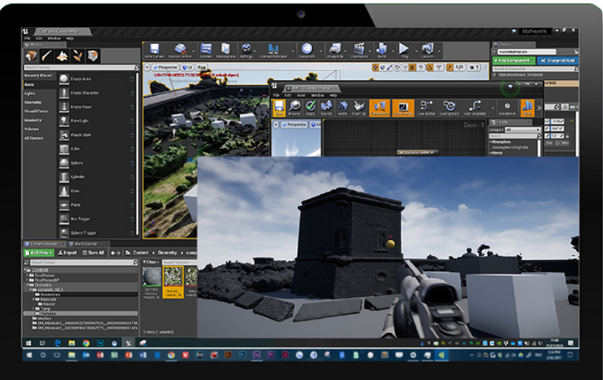

VIRTUAL

Notes

[I]The Royal Sites and the Residences of the Bourbons - throughout the Kingdom of the Two Sicilies and in particular in the metropolitan area of the Campania region - represent a 'territorial systems of hubs' acting as museums, residences, hunting estates, administrative centres, agricultural holdings, industrial sites and as places to protect environmental heritage [Alisio | 980 , pp. 72-85].

[2] Giovanni Antonio Medrano, Antonio Carnevari and Luigi Vanvitelli are the main architects involved.

[3] Cfr. Piante generali ed altre particolari di alcuni Siti delle Reali Delizie di Portici presentate alla Real Maestà Sua dal Cav. D. Vespasiano Macedonio Intendente delle stesse Reali Delizie (Bibl. Naz. di Napoli - Collezione Palatina) and the letter dated 29th November 1738 sent to "Ger Frnc.co faccia locchè se gli è comandato al giardino di Portici" (A.S.N. Casa Reale Amministrativa fasc. 1016 G.)

[4] Cfr. Relazione storica al PUC di Portici, 2012.

[5] Documentary sources contain many notes regarding works on the water supply system, excavations, transportation of earth and removal of stones. Cfr. Real Villa di Portici e sue Reali Fabbriche, A.S.N. Casa Reale Amministrativa, fasc. I0 I6, a. I739 et foll.

[6] In a letter dated I th March 1739, the Marquis of Salas wrote to Medrano about the drawings he had sent with several additions regarding the design of the fountains, statues and water features, as inVersailles. He also informed him about his decision to position the royal palace in such a way that its main door with the central fountain would be on an axis with the garden. 


\section{References}

Alisio G. (1959). Le ville di Portici. In Pane R. et al. (a cura di). Ville Vesuviane del Settecento. Napoli.

Alisio G. (1980). I Siti Reali. In Causa R. (a cura di). Civiltà del Settecento a Napoli (1 734- I 799). Firenze: Centro Di, pp. $72-85$.

Apollonio F.l. et. al. (20 I7). II restauro della fontana del Nettuno a Bologna. Un sistema 3D Web per la documentazione e la gestione dei dati. In Archeomatica, VIII-4.

Barbera F. (2006). Dalle ville nobiliari esoteriche al Palazzo Reale di Portici: il simbolismo del Sole e della Luna nella Santa Coppa. In Fagiolo M. (a cura di). Architettura e Massoneria. L'esoterismo della costruzione. Roma: Gangemi Editore.

Benedetti B. et al. (2008). Scientific knowledge and information representations in historical-technical archives of archaeological sites: Pompeii as a case study. In Responsibilities and opportunities in architectural conservation conference proceedings, $\mathrm{n}$. I.

Brusaporci S. (a cura di). (2010). Sistemi informativi integrati per la tutela, la conservazione e la valorizzazione del patrimonio architettonico e urbano. Roma: Gangemi Editore.

Cazzato V. (2016). Una "città di ville" alle falde del Vesuvio. In Giusti M.A. (a cura di). Ville lucchesi, d'Italia, del mondo. Lucca: Pacini Fazzi.

D’Argenville D. ( 1709). La thèorie et la pratique du jardinage. Cap.VII.

De Cunzo M. (1959). Le Ville Vesuviane. In Causa R. (a cura di). Civiltà del Settecento a Napoli (1 734- I 799). Firenze: Centro Di.

Di Stefano R., Trione A. (1979). II Miglio d'oro, itinerario fotografico attraverso le ville vesuviane di Pino Grimaldi. Napoli: II Laboratorio Edizioni.

Gamboni A., Neri P. (1987). Napoli-Portici. La prima ferrovia d'Italia: 1839. Napoli: Fausto Fiorentino Editrice.

Ippoliti E. et al. (2012). Interfacce e tecnologie visual 3D per conoscere, condividere e valorizzare il patrimonio culturale. Documentazione e Conservazione del Patrimonio Architettonico ed Urbano. In Disegnarecon, vol. 5, n. 10.

Maltese C. (a cura di). (1967). Francesco di Giorgio Martini. Trattati d'Architettura, ingegneria e arte militare. Milano: II Polifilo editore, vol. I.

Nex F., Remondino F. (20।4). UAV for 3D mapping applications: a review. In Applied Geomatics, n. 6.

Nicèron P. J. (1636). La perspective curiuse. Paris.

Nocerino N. (1787). La real villa di Portici. Napoli.

Papa L. M. (20I5). Cartografia e modelli di gestione dati. In Augenti N., Bontempi F. (a cura di). Ingegneria Forense. Crolli, affi dabilità strutturale e consolidamento. Palermo: Dario Flaccovio Editore.

Papa L. M. (2019). Considerations about Old Maps in the Digital Era. In The Representation of Landscape, Environment and Territory. Diségno, n. 5.

Papa L. M. et al. (2020). Un progetto di valorizzazione dei Siti Reali in Europa. II caso della Reggia di Portici in Campania. In Paesaggio Urbano, n. 2.

Papa L. M., D'Agostino P (2020). Un processo integrato di conoscenza e visualizzazione. II castello della Reggia di Portici. In A. Arena et al. (a cura di). Connettere. Un disegno per annodare e tessere. Atti del $42^{\circ}$ Convegno Internazionale dei Docenti delle Discipline della Rappresentazione/Connecting. Drawing for weaving relationships. Proceedings of the 42th International Conference of Representation Disciplines Teachers, pp. 25 I5-2532. Milano: Franco Angeli.

Pezza V. (2002). La costa orientale di Napoli. Il progetto e la costruzione del disegno urbano. Napoli: Electa.

Remondino F. (20I I). Heritage recording and 3D modeling with photogrammetry and 3D scanning. In Remote Sensing, vol. 3, n. 6.

Vella A. (1996). Trilogia della città vesuviana. In Quaderni vesuviani, n. 26.

\section{Author}

Giuseppe Antuono, Università degli Studi di Napoli Federico II, giuseppe.antuono@unina.it

To cite this chapter. Antuono Giuseppe (2021). Sistemi e modelli integrati di conoscenza e visualizzazione. II 'Bosco' del Real Sito di Portici/lntegrated Systems and Knowledge and Visualisation Models. The 'Woods' of the Royal Site of Portici. In Arena A. Arena M. Mediati D. Raffa P. (a cura di). Connettere Un disegno per annodare e tessere Linguagri Distanze Tecnologie. Atti del $42^{\circ}$ Convegno Internazionale dei Docenti delle Discipline della Rappresentazine Representation Disciplines Teachers. Milano: FrancoAngeli, pp. | $942-196 \mid$. 